INSTITUTO DE PESQUISAS ENERGÉTICAS E NUCLEARES

Autarquia Associada à Universidade de São Paulo

\title{
EFEITOS DE VARIÁVEIS DO PROCESSO DE GELIFICAÇÃO INTERNA NAS PROPRIEDADES FÍSICAS E QUÍMICAS DE MICROESFERAS DE ALUMINA
}

CHARLES DE MIRANDA CHRISTE

\begin{abstract}
Dissertação apresentada como parte dos requisitos para obtenção do Grau de Mestre em Ciências na Área de Tecnologia Nuclear - Materiais
\end{abstract}

Orientador:

Dr. Luis Antonio Genova

SÃO PAULO

2012 
Dedico este trabalho a meus pais queridos, Benedicto Christe e Maria Ap. de Miranda Christe que me apoiaram plenamente durante esta longa jornada. 


\section{AGRADECIMENTOS}

Após a realização deste trabalho, percebe-se que muitas pessoas contribuiram direta ou indiretamente para a esta conquista, às quais gostaria de humildemente agradecer, com todo o meu reconhecimento e gratidão.

Agradeço ao meu orientador Dr. Luis Antonio Genova, exemplo de profissionalismo e dedicação, pela confiança e oportunidade.

A minha irmã Fátima e em especial aos meus pais, Benedicto Christe e Maria Ap. de Miranda Christe, pela oportunidade de chegar até aqui, pelo carinho, dedicação, incentivo e orações.

A CAPES pelo auxílio concedido na forma de bolsa.

Aos amigos de laboratório, especialmente a Giovanna e Thiago Chagas, que tiveram a opurtunidade de vivenciar mais de perto meu trabalho; pela amizade, troca de sugestões, convívio e incentivo durante esta etapa.

A todos os colegas de laboratório, Augusto, Raissa e Rodrigo Pontes pela força.

Ao meu amigo Silas, pela amizade e dicas durante todo o meu trabalho.

A todos os colegas do Grupo de Materiais Cerâmicos, pesquisadores e alunos, Dra. Ana Helena de Ameida Bressiani, Dra. Érica, Dra. Ivana, Dra. Juliana Marchi, Ma. Karollina, Ma. Shirley, pelas sugestões

Aos técnicos de laboratório, Pedro, Yone, Rene e a todos os pesquisadores que colaboraram.

De uma maneira especial a Deus pelo privilégio de chegar onde estou, pela força, saúde, inspiração, ... enfim, por tudo que tem me proporcionado, minha sincera e eterna gratidão. 


\title{
EFEITOS DE VARIÁVEIS DO PROCESSO DE GELIFICAÇÃO INTERNA NAS PROPRIEDADES FÍSICAS E QUÍMICAS DE MICROESFERAS DE ALUMINA
}

\author{
Charles de Miranda Christe
}

\begin{abstract}
RESUMO
Microesferas cerâmicas vêm sendo utilizadas em diferentes aplicações, relacionadas à área nuclear, farmacêutica, química, médica, ambiental, biotecnológica, etc. É possível a obtenção, pelo método da gelificação interna, de microesferas de diferentes materiais cerâmicos, densas ou porosas (com porosidade controlada) e com diferentes tamanhos. No entanto o grande obstáculo é a formação de trincas na secagem e/ou calcinação, que podem inviabilizar a aplicação das mesmas. Este trabalho tem como objetivo a produção de microesferas a base de alumina $\left(\mathrm{Al}_{2} \mathrm{O}_{3}\right)$ pelo processo de gelificação interna, variando-se parâmetros de processamento de forma a se controlar as características físicas e químicas das mesmas, como tamanho, porosidade, superfície específica, etc., além de características específicas que viabilizem a aplicação das mesmas no preenchimento de colunas de eluição de geradores de ${ }^{99}$ Mo- ${ }^{99 m}$ Tc. Foi desenvolvida uma metodologia simples e eficiente de tratamento de lavagem das microesferas, que possibilita a extração de uma porção significativa da fase orgânica presente antes da secagem e calcinação; desta forma elimina-se praticamente todas as trincas que surgiriam durante a secagem, e principalmente na etapa de calcinação. Além disso, foram variados parâmetros de processo que permitem controlar a porosidade e superfície específica das microesferas. Foram também caracterizadas em paralelo, duas aluminas de transição na forma de pós, utilizadas atualmente no preenchimento de colunas do gerador de ${ }^{99} \mathrm{Mo-}^{99 \mathrm{~m}} \mathrm{Tc}$ de modo a se ter uma noção das atuais exigências quanto às propriedades fisicas do material de preenchimento.
\end{abstract}




\title{
VARIABLE EFFECTS OF THE INTERNAL GELATION PROCESS IN THE PHYSICAL AND CHEMICAL PROPERTIES OF ALUMINA MICROSPHERES
}

\section{Charles de Miranda Christe}

\begin{abstract}
Ceramic microspheres have been used in various applications, related to the nuclear, pharmaceutical, chemical, medical, environmental, biotechnology, etc. It is possible to obtain, by internal gelation method, microspheres of different ceramic materials, dense or porous (with controlled porosity) and different sizes. However, the major obstacle is the formation of cracks on drying and / or calcination, which can hinder their use. This study have an objective at the production of alumina $\left(\mathrm{Al}_{2} \mathrm{O}_{3}\right)$ based microspheres by internal gelation process, varying processing parameters in order to control the chemical and physical characteristics such as size, porosity, specific surface area, etc., in addition to specific characteristics that enable their application in filling of the elution columns of ${ }^{99} \mathrm{Mo}^{-99 \mathrm{~m}} \mathrm{Tc}$ generators. It was developed a simple and efficient method of washing treatment of the microspheres, which enables the extraction of a significant portion of the organic phase present prior to drying and calcination; thus virtually eliminates all cracks that arise during drying, and particularly in calcination step. In addition, process parameters were varied for controlling the porosity and specific surface of the microspheres. Were also characterized in parallel, two transition aluminas in the form of powders currently used in filling of elution columns of ${ }^{99} \mathrm{Mo}^{-}{ }^{99 \mathrm{~m}} \mathrm{Tc}$ generator so as to get an idea of the current requirements for physical properties of the filling material.
\end{abstract}




\section{SUMÁRIO}

1 - INTRODUÇÃO

2-OBJETIVO 4

3 - REVISÃO DA LITERATURA

3 -1 Gelificação Interna 5

3 - 2 Reações durante a gelificação interna 5

3 - 3 Etapa de lavagem das microesferas

3-4 Aplicação da alumina em gerador de ${ }^{99} \mathrm{Mo} /{ }^{99 m} \mathrm{Tc} \quad 8$

4 - MATERIAIS E MÉTODOS 10

4 - 1 Variação na composição 10

4 - 2 Eliminação das trincas (lavagem e calcinação) 12

4 - 3 Distribuição de tamanho das microesferas 14

5 - RESULTADOS E DISCUSSÃO 16

5 - 1 Caracterização das aluminas comerciais 16

5 - 1 - 1 Picnometria de He: 16

5 - 1 - 2 Difração de raios X 16

5 - 1 - 3 Distribuição de tamanho de aglomerados 20

5 - 1 - 4 Micrografias dos aglomerados 20

5 - 1 - 5 Superfície específica das aluminas comerciais 20

5 - 1 - 6 Transformação das fases das aluminas comerciais 21

5 - 2 Caracterização das microesferas de alumina 26

5 - 2 - 1 Curvas de perda de massa por análise termogravimétrica 26

5 - 2 - 2 Condutividade elétrica das soluções após lavagem 30

5 - 2 - 3 Transformação de fases com a calcinação 32

5 - 2 - 4 Superfície específica e porosidade das microesferas 32

6 - CONCLUSÕES

7 - REFERÊNCIAS BIBLIOGRÁFICAS 44 


\section{1 - INTRODUÇÃO}

Alumina é o nome genérico das diferentes fases cristalinas do óxido de alumínio $\left(\mathrm{Al}_{2} \mathrm{O}_{3}\right)$ obtidas a partir de hidróxidos precursores, os tri-hidróxidos gibsita, bayerita e nordstrandita $\left(\mathrm{Al}(\mathrm{OH})_{3}\right)$ e os mono-hidróxidos boemita, diáspora e a pseudoboemita $(\mathrm{AlO}(\mathrm{OH}))$.

Dependendo do hidróxido precursor e do tratamento térmico de calcinação,

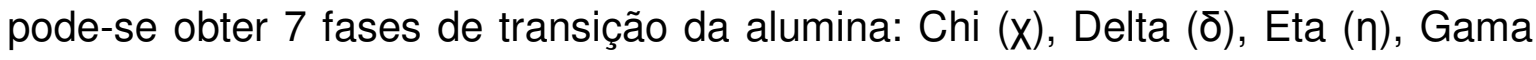
$(\mathrm{\gamma})$, Kapa $(\kappa)$, Rho $(\rho)$ e Teta $(\theta)$ e uma fase estável, a alfa ( $\alpha$ ), que é obtida a partir de qualquer um dos hidróxidos, quando calcinados acima de $1100{ }^{\circ} \mathrm{C}$. $\mathrm{Na}$ Tabela I são apresentadas as estruturas cristalinas destas fases da alumina.

Tabela I - Fases cristalinas da alumina.

\begin{tabular}{|c|c|c|}
\hline & Fase & Sistema Cristalino \\
\hline \multirow[b]{2}{*}{ ALUMINAS } & \multirow[t]{2}{*}{$\gamma$} & Tetragonal \\
\hline & & Espinélio (cúbico) \\
\hline \multirow{4}{*}{ DE } & $\eta$ & Espinélio (cúbico) \\
\hline & \multirow[t]{2}{*}{$\delta$} & Ortorrômbico \\
\hline & & Tetragonal \\
\hline & $\theta$ & Monoclínico \\
\hline \multirow[b]{2}{*}{ TRANSIÇÃO } & & Monoclínico \\
\hline & $\lambda$ & Monoclínico \\
\hline \multirow{3}{*}{ OU } & \multirow[t]{2}{*}{$\chi$} & Cúbica \\
\hline & & Hexagonal \\
\hline & ATIVAS & Hexagonal \\
\hline FASE ESTÁVEL & $\alpha$ & Hexagonal \\
\hline
\end{tabular}


As aluminas de transição (também chamadas de aluminas ativas ou ativadas) são utilizadas amplamente em diversos ramos da indústria como a química e a farmacêutica, por apresentarem características de superfície (por exemplo, textura, morfologia, elevada superfície específica, sítios ácidos e básicos, alta porosidade) que permitem seu uso como catalisadores ou suporte de catalisadores, trocadores iônicos, colunas cromatográficas, filtros seletivos, absorvedores, etc.

A alumina é utilizada no preenchimento da coluna de eluição do gerador do radiofármaco ${ }^{99} \mathrm{Mo}^{-}{ }^{99 \mathrm{~m}} \mathrm{Tc}$ e suas características determinam em grande parte a qualidade do gerador. Um dos objetivos deste trabalho é o desenvolvimento de microesferas de aluminas com características adequadas ao preenchimento das colunas de eluição, e que isso permita promover um aumento no rendimento dos geradores produzidos no IPEN.

As microesferas cerâmicas podem ser obtidas pelos métodos de gelificação interna ou de gelificação externa, sendo possível, a princípio, a produção de microesferas de todos os óxidos insolúveis em água, ou seja, os óxidos da maioria dos elementos químicos.

O processo de gelificação interna foi originalmente desenvolvido nos laboratórios da Keuring van Electro technische Material ematAenhem (Kema) ${ }^{(1)}$, Holanda, sendo posteriormente extensivamente estudado, principalmente no Oak Ridge Nacional Laboratory (ORNL) para a produção de combustíveis nucleares na forma de microesferas de $\mathrm{UO}_{2},(\mathrm{U}, \mathrm{Pu}) \mathrm{O}_{2}$, $\mathrm{ThO}_{2}$, e $\left(\mathrm{UO}_{2}+\mathrm{UC}_{2}\right)$ para serem utilizados nos reatores de leito fluidizado, de alta temperatura e refrigerado a gás.

O processo de gelificação externa foi desenvolvido na Itália ${ }^{(1)}$, e tinha como objetivo converter a solução de nitrato de uranila em microesferas sem que ocorresse a redução do $U^{6+}$ para $U^{4+}$.

Apesar do termo "microesfera" sugerir relação à escala (micrometros), vem sendo utilizado para descrever esferas em uma ampla faixa de diâmetros, desde nanométricas até aquelas de escala milimétrica.

O método da gelificação interna ${ }^{(2-17)}$ é um dos principais métodos utilizados para a produção de microesferas cerâmicas, sendo um processo 
simples e adequado para manusear produtos radioativos, evitando o manuseio destes na forma de pós secos.

De um modo resumido as microesferas cerâmicas são produzidas em coluna de gelificação, com uma solução contendo o íon de interesse, uréia e hexametilenotetramina sendo gotejada em uma coluna contendo um líquido imiscível (normalmente um óleo) aquecido a aproximadamente $90{ }^{\circ} \mathrm{C}$; ao entrar em contato com este líquido aquecido, as gotas experimentam um aumento brusco de temperatura, ocorrendo um conjunto de reações químicas (complexação do íon metálico pela uréia, protonação das moléculas de HTMA, e decomposição do HMTA em formaldeído e amônia) a ureia atua como agente complexante aumentando $\mathrm{o} \mathrm{pH}$ da solução e a consequente precipitação e gelificação destas gotas na forma de pequenas esferas.

As microesferas são mantidas por algum tempo no óleo aquecido, e após isso são separadas e lavadas para posterior secagem e calcinação.

O principal problema relacionado à produção de microesferas cerâmicas é o surgimento de trincas nas mesmas durante a secagem e, principalmente, a calcinação, que podem prejudicar sua aplicação. Uma das principais contribuições deste estudo foi o desenvolvimento de uma metodologia simples, de baixo custo e eficiente, para a obtenção de microesferas cerâmicas praticamente isentas de trincas. 


\section{2 - OBJETIVO}

O objetivo deste trabalho é estudar o processo de gelificação interna e suas variáveis de modo a se poder controlar as características físicas e químicas de microesferas de alumina. Para que estas microesferas possam ser aplicadas com eficiência, estudou-se também algumas metodologias que permitissem a produção de microesferas isentas de trincas. Quanto à aplicação, a meta é o desenvolvimento de microesferas de alumina que possam ser utilizadas para 0 preenchimento das colunas de eluição dos geradores de ${ }^{99} \mathrm{Mo}-{ }^{-99 m} \mathrm{Tc}$, de forma a conferir aos mesmos um maior rendimento, comparado aos geradores atualmente produzidos. 


\section{3 - REVISÃO DA LITERATURA}

\section{3 - 1 GELIFICAÇÃo INTERNA}

Um dos principais métodos para a produção de microesferas cerâmicas é o método da gelificação interna, processo simples, e adequado para manusear materiais radioativos, evitando o manuseio destes materiais na forma de póssecos. Pelo método da gelificação interna ${ }^{(18-20)}$, uma solução aquosa contendo íon metálico de interesse (por exemplo, solução de nitrato de alumínio), hexametilenotetramina (HMTA - $\left.\mathrm{C}_{6} \mathrm{H}_{12} \mathrm{~N}_{4}\right)$ e ureia $\left(\mathrm{CO}\left(\mathrm{NH}_{2}\right)_{2}\right)$, mantida a temperatura de $5^{\circ} \mathrm{C}$, é gotejada em uma coluna contendo um líquido imiscível (óleo, por exemplo), pré-aquecido a uma temperatura adequada (acima de $60 \stackrel{\circ}{ } \mathrm{C}$, mas normalmente a $90^{\circ} \mathrm{C}$ ). Ao ser aquecida pelo líquido imiscível, a gota da solução experimenta diferentes reações, descritas a seguir, com o consequente aumento de pH que provoca a gelificação da solução. O tamanho das gotas e, portanto das microesferas finais, é definido pela vazão de alimentação da solução, pelo tamanho do orifício do bico gotejador, e pela tensão interfacial entre os dois meios, o óleo e o líquido na gota. Ao cair na coluna de óleo, a gota mantém sua forma esférica devido à diferença entre as tensões superficiais do óleo e da solução contida na gota. A variação de tamanho das microesferas obtidas está relacionada com a maneira empregada para a formação das gotas: se por aspersão, pulverização, gotejamento, se é aplicado vibração mecânica, ultrasom, etc., além de diversas outras variáveis que também podem interferir no tamanho das gotas. ${ }^{(22,23)}$

\section{3 - 2 REAÇÕES DURANTE A GELIFICAÇÃO INTERNA}

Ao entrar em contato com o líquido imiscível aquecido, a solução contida na gota experimenta as seguintes reações, que provocam a precipitação e gelificação da mesma:

- Reação 1, de complexação, a ureia atua como agente complexante do íon metálico, evitando que ocorra precipitação em temperaturas baixas:

$$
2 \mathrm{CO}\left(\mathrm{NH}_{2}\right)_{2}+\mathrm{Al}^{3+} \leftrightarrow \mathrm{Al}\left[\mathrm{CO}\left(\mathrm{NH}_{2}\right)_{2}\right]_{2}^{3+}
$$

- Reação 2, de protonação das moléculas de HTMA: 


$$
\left(\mathrm{CH}_{2}\right)_{6} \mathrm{~N}_{4}+\mathrm{H}^{+} \leftrightarrow\left(\mathrm{CH}_{2}\right)_{6} \mathrm{~N}_{4} \cdot \mathrm{H}^{+}
$$

- Reação 3, decomposição do HMTA em amônia e formaldeído (a uréia tem também a função de retardar esta decomposição):

$$
\left(\mathrm{CH}_{2}\right)_{6} \mathrm{~N}_{4} \cdot \mathrm{H}^{+}+3 \mathrm{H}^{+}+6 \mathrm{H}_{2} \mathrm{O} \leftrightarrow 4 \mathrm{NH}_{4}^{+}+6 \mathrm{CH}_{2} \mathrm{O} \text {. }
$$

J. L. Collins e colaboradores apresentam ampla literatura quanto ao processo, produzindo microesferas de diferentes óxidos (de $\mathrm{U}, \mathrm{Th}, \mathrm{Al}, \mathrm{Zr}, \mathrm{Ce}$, etc.), tamanhos e porosidade ${ }^{(21,24-26)}$. Microesferas de óxido de urânio foram produzidas em uma coluna com aproximadamente $550 \mathrm{~mm}$ de altura, com o óleo aquecido a $60 \stackrel{\circ}{ } \mathrm{C}$; estas microesferas foram mantidas no óleo por $30 \mathrm{~min}$ (tempo de envelhecimento). Após isso as microesferas passaram por uma etapa de sucessivas lavagens com tricloroetileno até a completa remoção do óleo. A seguir as microesferas são imersas seguidas vezes em solução de amônia a 0,5M para a retirada do tricloroetileno, e finalmente são lavadas em água destilada em abundância para a eliminação da solução de amônia. Após esta etapa de lavagem as microesferas são secas ao ar e em estufa e por fim são calcinadas (28).

Pesquisas posteriores realizadas no Oak Ridge National Laboratory (ORNL), produziram microesferas de diferentes óxidos, e mostraram que as microesferas têm seu tamanho significativamente reduzido, passando por exemplo, de 1000 um de diâmetro após secagem ao ar, para diâmetros entre 350 e $500 \mu \mathrm{m}$ após sinterização ${ }^{(30)}$.

Collins e colaboradores propuseram diferentes rotas para eliminar o principal problema do processo de produção, que é o surgimento de trincas nas microesferas durante as etapas de secagem e calcinação. Uma das propostas apresentadas por Collins e co-autores, por exemplo, foi a prévia fervura por longos períodos, da solução contendo ureia e HMTA, sob refluxo ${ }^{(26)}$; os autores sugeriam que com esta fervura podia-se eliminar moléculas de gases dispersas na solução, que seriam a causa da formação de trincas durante a secagem e/ou calcinação. 


\section{3 - 3 ETAPA DE LAVAGEM DAS MICROESFERAS}

Nos últimos anos a etapa de lavagem, que ocorre após a gelificação e o período de envelhecimento, começou a adquirir uma importância decisiva na produção de microesferas. Inicialmente foi descrita na literatura como tendo a função de retirar o óleo e possíveis íons nitrato da superfície das microesferas, e seguia a seguinte sequência: as microesferas eram imersas e mantidas por 60 min, em uma solução contendo um solvente orgânico (tetracloreto de carbono $\mathrm{CCl}_{4}$, tricloroetileno - TCE ou hexano) que extrairá o óleo de sua superfície. Este procedimento era repetido de duas a quatro vezes. Após esta etapa as microesferas eram imersas e mantidas também por 60 min., em solução diluída de $\mathrm{NH}_{4} \mathrm{OH}$, cuja função é extrair o solvente residual e possíveis íon nitrato (procedimento repetido também de duas a quatro vezes). Por fim, as microesferas eram imersas e mantidas em água destilada para a eliminação do resíduo de $\mathrm{NH}_{3}$. Após isso as microesferas eram secas ao ar por $24 \mathrm{~h}$, depois em estufa a $110{ }^{\circ} \mathrm{C}$, podendo então ser calcinadas. No entanto, com esta sequência, observa-se o surgimento de trincas nas microesferas durante a secagem e calcinação.

Em publicação recente ${ }^{(27,28)}$, Hunt e co-autores sugeriram que a etapa de lavagem poderia ser mais explorada, e que nesta etapa poderia-se extrair parte da fração orgânica presente nas microesferas, oriundas das reações envolvendo a HMTA e ureia da solução inicial. A eliminação desta fase orgânica durante a calcinação seria a origem da formação de trincas. Assim, com a extração de parte desta fase orgânica na etapa de lavagem, haveria menor quantidade a ser eliminada na calcinação, e consequentemente a ocorrência de trincas seria reduzida ou eliminada. Os autores sugeriram que as microesferas fossem tratadas na seguinte sequência: TCE, $\mathrm{NH}_{4} \mathrm{OH}$, água (até aqui o procedimento tradicional) e posteriormente tratada com água sob pressão (autoclavagem das microesferas imersas em água, a $200{ }^{\circ} \mathrm{C}$ por 180 minutos), e a seguir imersas e mantidas por um tempo mínimo de 30 min. em Dowanol $\mathrm{PM},\left(\mathrm{CH}_{3} \mathrm{OCH}_{2^{-}}\right.$ $\mathrm{CH}(\mathrm{OH}) \mathrm{CH}_{3}$ - éter metil propileno glicol), um produto comercial produzido pela Aldrich Chemical Co., procedimento este, repetido por 5 vezes. Após a lavagem com Dowanol PM, novamente as microesferas foram submetidas a lavagem com água destilada em abundância, até que a condutividade elétrica desta água 
estabilizasse. Por fim as microesferas foram submetidas a mais uma lavagem com Dowanol PM.

De acordo com os autores a autoclavagem a $200{ }^{\circ} \mathrm{C}$ dissolveria parte da fase orgânica presente nas microesferas (lixiviação), e o produto Dowanol PM auxiliaria na evaporação da água durante a secagem das microesferas.

Alguns autores ${ }^{(20)}$ propõem a não utilização de solvente orgânico durante a lavagem das microesferas, que são imersas diretamente em solução de amônia a uma temperatura de $80^{\circ} \mathrm{C}$, com posterior lavagem em água destilada, também a $80 \stackrel{\circ}{\circ}$.

Microesferas de óxido de tório ${ }^{(22)}$ obtidas pelo processo de gelificação interna foram lavadas com solução amoniacal, seguida de lavagem em etanol. Após isso foram secas ao ar e calcinadas em forno tipo mufla, a $1100 \stackrel{\circ}{\mathrm{C}}$.

Outros autores eliminaram a lavagem com solução de amônia, passando diretamente da lavagem com o solvente orgânico para a lavagem com água destilada a quente $\left(90{ }^{\circ} \mathrm{C}\right)$ durante várias horas, para extrair principalmente $\mathrm{O}$ nitrato.

3- 4 APLICAÇÃO DA ALUMINA EM GERADOR DE ${ }^{99}$ MO/ ${ }^{99 M} T C$

Os radiofármacos produzidos a partir do gerador de ${ }^{99} \mathrm{Mo} /{ }^{99 \mathrm{~m}} \mathrm{Tc}$ respondem por mais de $70 \%$ dos 3 milhões de procedimentos anuais na medicina nuclear. De uma forma simples este gerador é composto por uma coluna de alumina, na qual é adsorvido o ${ }^{99} \mathrm{Mo}$ (na forma de molibdato, ${ }^{99} \mathrm{MoO}^{2-}{ }_{4}$ ); este ${ }^{99} \mathrm{Mo}$ decai a ${ }^{99 \mathrm{~m}} \mathrm{Tc}$, que por não ter afinidade com a alumina pode ser extraído da coluna por meio de uma solução salina (eluente). Este ${ }^{99 \mathrm{~m}} \mathrm{Tc}$, que é obtido na forma de pertecnetato $\left({ }^{99 \mathrm{~m}} \mathrm{TcO}_{4}^{-}\right)$, pode ser combinado com uma variedade de substâncias (carreadores) originando os diferentes radiofármacos para aplicações específicas.

A alumina utilizada na coluna do gerador de ${ }^{99} \mathrm{Mo} /{ }^{99 m} \mathrm{Tc}$ desempenha um papel determinante para o sucesso do mesmo. As principais funções e atividades desta alumina são listadas abaixo:

- Deve adsorver a máxima quantidade possível de ${ }^{99} \mathrm{Mo}$, mantendo esta adsorção estável ao longo do tempo, mesmo com a presença do eluente,

- Liberar o máximo de ${ }^{99 m}$ Tc formado, com o menor volume de eluente possível, 
- Deve possuir distribuição de tamanho de partículas e porosidade tais que o seu empacotamento na coluna permita uma adequada permeabilidade do eluente sob o efeito do vácuo,

- E por fim, que seja quimicamente estável, de modo a não ocorrer liberação de íons $\mathrm{Al}^{3+}$ no eluente.

Existe uma grande demanda da área de Medicina Nuclear para que sejam produzidos geradores mais potentes, que possam ser utilizados em um maior número de procedimentos e por tempos maiores. Um dos principais limitadores para esta evolução é a quantidade de ${ }^{99}$ Mo capaz de ser adsorvido na alumina. Grandes esforços estão sendo despendidos na mudança do design da coluna e principalmente na ampliação da capacidade de adsorção da alumina, sem que isso prejudique as demais funções envolvidas.

As diferentes funções e atividades da alumina dependem de características que se contrapõem: por exemplo, a máxima adsorção iônica está relacionada à elevada área de superfície específica, que por sua vez é obtida sob baixas temperaturas de calcinação. No entanto, aluminas calcinadas em baixas temperaturas apresentam maior liberação de íon Al. Desta forma deve-se ter um rígido controle das características físicas e químicas da alumina, encontrando um ponto de equilíbrio entre os parâmetros que interferem no seu desempenho: pureza, área de superfície específica $\left(\mathrm{m}^{2} / \mathrm{g}\right)$, volume de poros $(\mathrm{ml} / \mathrm{g})$, diâmetro de poros $(\AA)$, distribuição e tamanho médio de partículas $(\mu \mathrm{m})$, fase cristalina e $\mathrm{pH}$. 


\section{4 - MATERIAIS E MÉTODOS}

A primeira etapa deste estudo foi caracterizar duas aluminas de transição comerciais, na forma de pós, que são indicadas para o preenchimento das colunas de eluição dos geradores de ${ }^{99} \mathrm{Mo} /{ }^{99 \mathrm{~m}} \mathrm{Tc}$. As aluminas Merck e ICN, como recebidas da Diretoria de Radiofármacos do IPEN (DIRF), foram tratadas termicamente entre 700 e $1200{ }^{\circ} \mathrm{C}$, com taxa de aquecimento de $5{ }^{\circ} \mathrm{C} / \mathrm{min}$, por uma e seis horas de patamar, sendo então caracterizadas quanto à área de superfície específica, morfologia e tamanho de aglomerados, e difração de raios X. O objetivo desta etapa foi conhecer as propriedades e características destas aluminas, que servirão como um padrão na comparação com as microesferas que serão estudadas.

$\mathrm{Na}$ figura 1 é apresentado um fluxograma geral do processo utilizado para a confecção das microesferas de alumina. Partindo-se de duas soluções contendo os reagentes, estas são misturadas a frio $\left(3 \mathrm{a}^{\circ} \mathrm{C}\right)$ de forma a inibir a gelificação, que deverá ocorrer somente quando a mistura for gotejada em coluna contendo óleo aquecido.

Na figura 2 é mostrado detalhe do gotejamento da solução na coluna de gelificação. Neste estudo utilizou-se óleo de silicone, aquecido a $90^{\circ} \mathrm{C}$, mas sabese que a gelificação pode ocorrer acima de $60{ }^{\circ} \mathrm{C}$. As microesferas gelificadas foram mantidas por $1 \mathrm{~h}$ no óleo aquecido para que ocorresse o processo de envelhecimento (para que toda a reação se completasse).

Partindo-se deste procedimento básico foram realizados diferentes experimentos, variando-se os parâmetros de processo, de modo a se ter 0 controle das características finais das microesferas obtidas.

\section{4 - 1 VARIAÇÃO NA COMPOSIÇÃO}

Foram realizados 5 diferentes experimentos variando-se a relação dos reagentes na solução a ser gelificada. As composições avaliadas são apresentadas na Tabela II. As microesferas obtidas com estes experimentos foram caracterizadas quanto ao tamanho, superfície específica e porosidade. Cabe ressaltar que a composição "C" foi considerada a composição padrão para os demais estudos deste trabalho. 


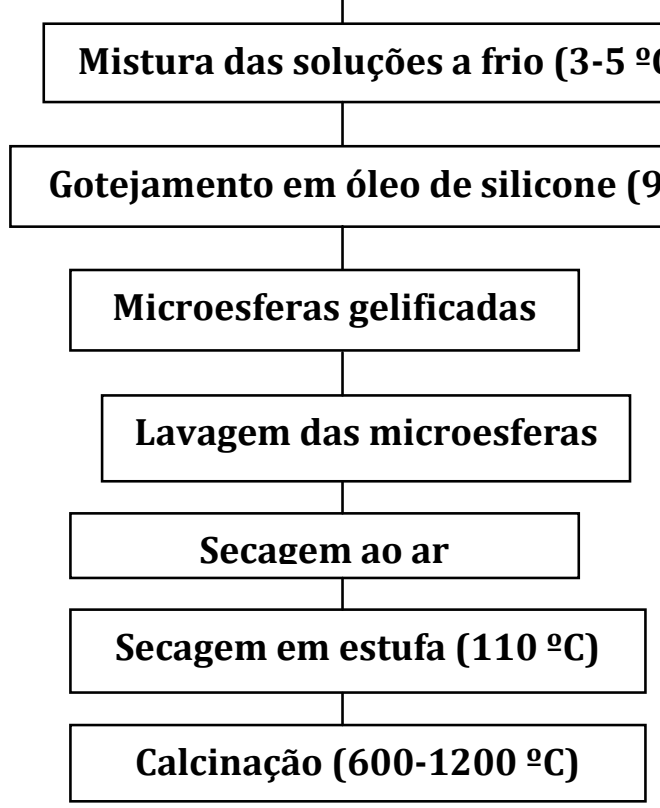

Figura 1 - Fluxograma do processo de obtenção de microesferas por gelificação interna.

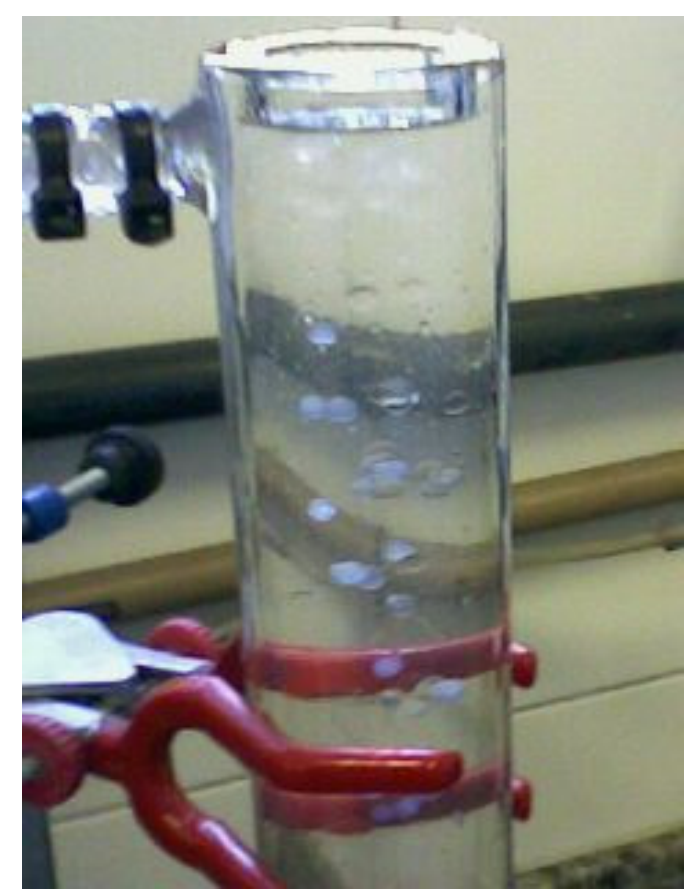

Figura 2 - Detalhe do processo de produção de microesferas por gelificação interna. 
$\mathrm{Na}$ tabela II são apresentadas as composições testadas neste estudo, variandose a relação entre os componentes. A composição $C$ foi considerada inicialmente como uma composição padrão deste estudo, tendo sido empregada nos estudos posteriores, de lavagem. As demais composições, como mostra a tabela, são variações dos componentes da composição $C$. A composição $D$, com menor teor de água, como será visto posteriormente, também apresentou resultados muito interessantes. A composição E, com maior teor de água, apresentou baixa resistência mecânica do gel, com alta deformação das microesferas e grande número de trincas na secagem e calcinação. Já a composição $F$, por outro lado, não promoveu a gelificação e, portanto, a formação de microesferas, por ter uma quantidade insuficiente dos agentes gelificantes, a ureia e o HMTA. Por último, a composição $\mathrm{G}$, com menor teor do nitrato de alumínio, também apresentou baixa resistência mecânica, deformação e elevada quantidade de trincas.

Tabela II - Variação dos componentes do processo de gelificação interna.

\begin{tabular}{|c|c|c|c|c|}
\hline Composição & $\begin{array}{c}\mathrm{Al}\left(\mathrm{NO}_{3}\right)_{3} \cdot 9 \mathrm{H}_{2} \mathrm{O} \\
(\mathrm{g})\end{array}$ & $\begin{array}{c}\text { Uréia } \\
(\mathrm{g})\end{array}$ & $\begin{array}{c}\mathrm{HMTA} \\
(\mathrm{g})\end{array}$ & $\begin{array}{c}\mathrm{H}_{2} \mathrm{O} \\
(\mathrm{ml})\end{array}$ \\
\hline C & 100 & 32 & 60 & 40 \\
\hline D & 100 & 32 & 60 & 30 \\
\hline E & 100 & 32 & 60 & 50 \\
\hline F & 100 & 25,6 & 48 & 32 \\
\hline$G$ & 100 & 38 & 72 & 48 \\
\hline
\end{tabular}

As composições $C$ e D, foram calcinadas a diferentes temperaturas (600, 700 e $900 \stackrel{\circ}{\circ} / 1 \mathrm{~h}$ ), e caracterizadas quanto às fases cristalinas presentes, a porosidade e a superfície específica.

\section{4 - 2 ELIMINAÇÃO DAS TRINCAS (LAVAGEM E CALCINAÇÃO)}

Foram realizados diferentes experimentos, como a fervura preliminar da solução de HMTA+uréia, conforme sugere as referências 10 a 12, variação das taxas de aquecimento e introdução de patamares intermediários durante a calcinação, redução do teor total de líquido, redução do teor de HMTA e ureia, 
todos com o objetivo de se eliminar a formação de trincas nas microesferas. Apesar de se observar algumas melhorias com estas medidas, nenhuma pode ser considerada eficiente para a eliminação completa das trincas.

Por outro lado, seguindo a sugestão de Hunt e co-autores ${ }^{(13)}$, foram realizados diversos experimentos durante a etapa de lavagem das microesferas, buscando-se extrair nesta etapa, o máximo da fase orgânica, com a consequente redução da massa a ser retirada durante a calcinação. Foram repetidas as etapas sugeridas pelo autor, com o uso do Dowanol PM, mas buscou-se também simplificar a metodologia, eliminando-se o uso deste produto, e utilizando-se autoclave de esterilização ao invés da autoclave mais robusta.

Após as etapas de lavagem tradicional (quatro procedimentos de imersão em TCE, cada um mantido por $1 / 2 \mathrm{~h}$; quatro imersões em solução diluída, 0,5 $\mathrm{mol} / \mathrm{L}$, de $\mathrm{NH}_{4} \mathrm{OH}$ também por $1 / 2 \mathrm{~h}$, e por fim a lavagem em água destilada em abundância por $1 / 2 h$ ), as microesferas foram submetidas a tratamentos de fervura (imersas em água em ebulição), variando-se o tempo de fervura e a quantidade de tratamentos, ou foram submetidas a tratamento em uma autoclave de esterilização comercial (com as microesferas imersas em água destilada sob pressão, a 134 ㄷ C por uma hora), que é bem mais simples e viável economicamente que o equipamento usado pelos autores citados (sob pressão a $200 \stackrel{\circ}{\circ}$ por 3 horas). Por fim todas as microeferas passaram por mais uma etapa de lavagem com água destilada.

Após a lavagem as microesferas foram secas ao ar por 24 horas, seguida de secagem em estufa a $110^{\circ} \mathrm{C}$, também por $24 \mathrm{~h}$. Após estes tratamentos, parte das microesferas foi submetidas a análise termogravimétrica e o restante foi calcinada a diferentes temperaturas $(600,700$ ou $900 \stackrel{\circ}{\circ}$ por uma hora de patamar, mantendo a taxa de aquecimento em $2 \stackrel{\circ}{\circ}$ /minuto).

Todas as etapas de lavagem das microesferas foram monitoradas medindo-se o pH e a condutividade elétrica da água após cada tratamento, sendo que a medida da condutividade elétrica se mostrou bastante eficiente para a detecção da eficiência destes tratamentos na retirada da fase orgânica das microesferas. Após a secagem as microesferas foram calcinadas a uma temperatura de $700^{\circ} \mathrm{C}$ por $1 \mathrm{~h}$ em forno Lindberg, com taxa de aquecimento de 2 
${ }^{\circ} \mathrm{C} / \mathrm{min}$.. Estes experimentos permitiram a completa eliminação das trincas quando calcinadas na temperatura de $700 \stackrel{\circ}{\circ}$, pois foram muito eficientes na extração da fase orgânica como pode ser constatado por medidas de condutividade elétrica após cada lavagem e por análise termogravimétrica, apresentadas à frente.

\section{4 - 3 DISTRIBUIÇÃO DE TAMANHO DAS MICROESFERAS}

As gotas foram formadas na coluna de gelificação de duas formas: pelo livre gotejamento da solução na coluna ou pela introdução de um jato da solução já no interior do óleo (o jato, por diferença de tensão superficial com o óleo, se transforma em gotas da solução) Para a avaliação da distribuição de tamanho das microesferas, foram variados dois parâmetros: o diâmetro do orifício do dispositivo de saida da solução (em forma de gota ou de jato) e a pressão aplicada no caso do jato. Foram testadas agulhas com diferentes orifícios $(0,3,0,5$ e $0,7 \mathrm{~mm})$, buscando-se produzir gotas ou jatos com diferentes dimensões. Os orifícios de tamanho 0,3 e $0,5 \mathrm{~mm}$ apresentaram constante entupimento, dificultando a utilização das agulhas com estes orifícios. Variou-se também a pressão com que a solução foi injetada no óleo aquecido. Na figura 3 é mostrado o sistema de gotejamento/injeção da solução, construido para que seja possível a variação do orifício e da pressão aplicada.

As microesferas obtidas (após lavagem e secagem a $110{ }^{\circ} \mathrm{C}$ e após calcinação a $700{ }^{\circ} \mathrm{C}$ ) foram fotografadas em estereoscópio NIKON e analisadas quanto ao tamanho por meio do software de análise de imagens Image Tool ${ }^{(29)}$. 


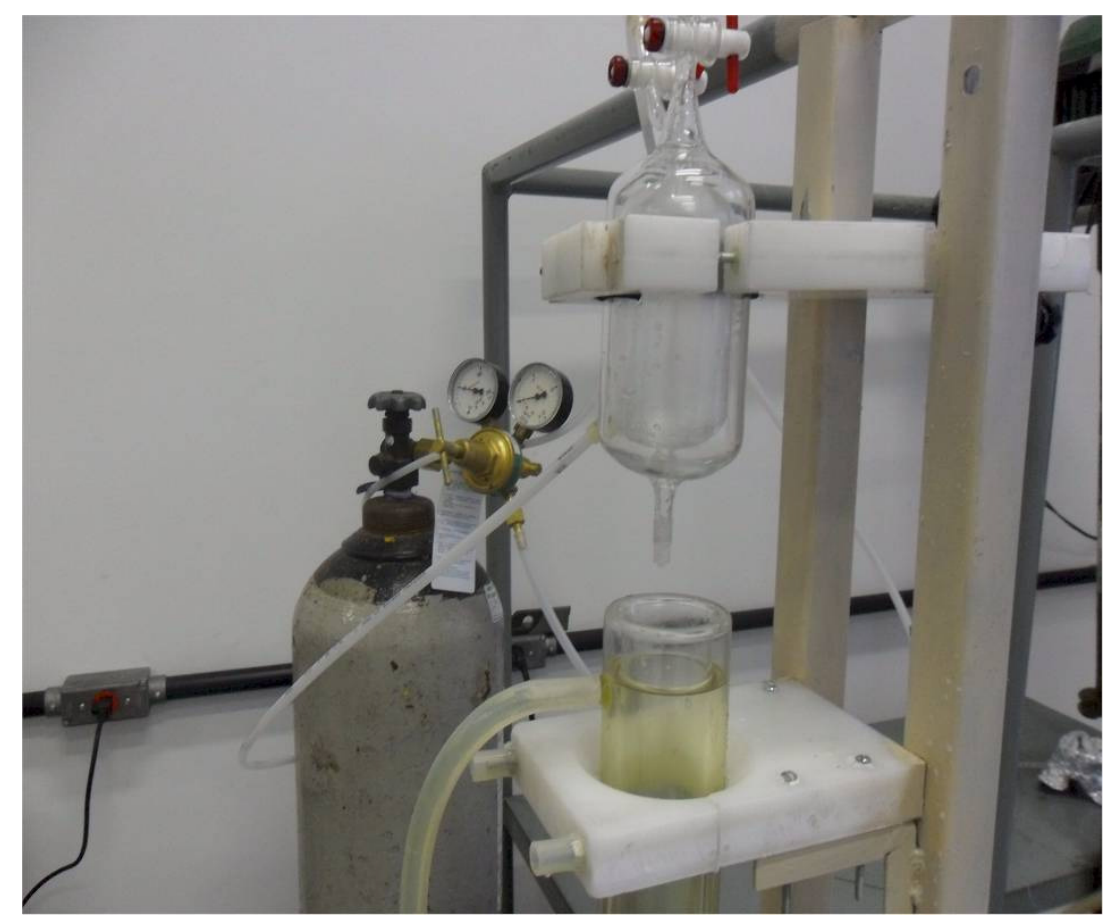

Figura 3 - Dispositivo para a variação das condições de gotejamento da solução no processo de gelificação interna. 


\section{5 - RESULTADOS E DISCUSSÃO}

\section{5 - 1 CARACTERIZAÇÃO DAS ALUMINAS COMERCIAIS}

As aluminas comerciais estudadas, Merck e ICN, assim como a alumina Merck calcinada na DIRF, e atualmente utilizada para o preenchimento das colunas de eluição foram caracterizadas quanto a densidade real, por meio de picnometria de Helio, quanto à morfologia e tamanho de aglomerados, por microscopia eletrônica de varredura, e quanto às fases cristalinas presentes, por difração de raios $X$. Estas aluminas serão designadas como MNC (Merck não calcinada, como recebida), ICN (não calcinada, como recebida) e MC (Merck calcinada pela DIRF).

\section{5 - 1 - 1 Picnometria de He:}

As aluminas foram analisadas por picnometria de He (Pycnometer 1305, Micromeritics), sendo os resultados apresentados na Tabela III:

Tabela III - Valores de densidade real das aluminas estudadas obtidos por picnometria de He.

\begin{tabular}{|c|c|}
\hline Alumina & Densidade $\left(\mathrm{g} / \mathrm{cm}^{3}\right)$ \\
\hline MC & 3,95 \\
\hline MNC & 3,18 \\
\hline ICN & 3,22 \\
\hline
\end{tabular}

A densidade teórica da alumina alfa é 3,98 $\mathrm{g} / \mathrm{cm} 3$, e assim pode-se afirmar que a alumina MC possui mais que $97 \%$ de fase alfa, com um resíduo menor que $3 \%$ da fase de transição presente na alumina original (MNC).

Os valores encontrados para as aluminas MNC e ICN estão em concordância com os valores de densidade para as fases de transição da alumina.

\section{5 - 1 - 2 Difração de raios $X$}

Nas figuras a seguir são apresentados os difratogramas obtidos para as amostras: Constata-se que a calcinação a que foi submetida a alumina Merck promoveu a transformação praticamente completa das fases de transição em fase 
alfa. Este fato pode ser constatado, além dos picos observados no difratograma de raios $X$, pela significativa redução da superfície específica (que passou de aproximadamente $170 \mathrm{~m}^{2} / \mathrm{g}$ para $15 \mathrm{~m}^{2} / \mathrm{g}$ ) e pela medida de densidade real obtida por picnometria de He. A diferença entre o valor de densidade para MC (3,95 $\left.\mathrm{g} / \mathrm{cm}^{3}\right)$ e o valor da densidade teórica da fase alfa $\left(3,98 \mathrm{~g} / \mathrm{cm}^{3}\right)$ indica, como já discutido, a presença de pequeno percentual (abaixo do limite de detecção do difratômetro de raios $X$, que é em torno de $4 \%$ em volume) de alumina de transição não transformada.

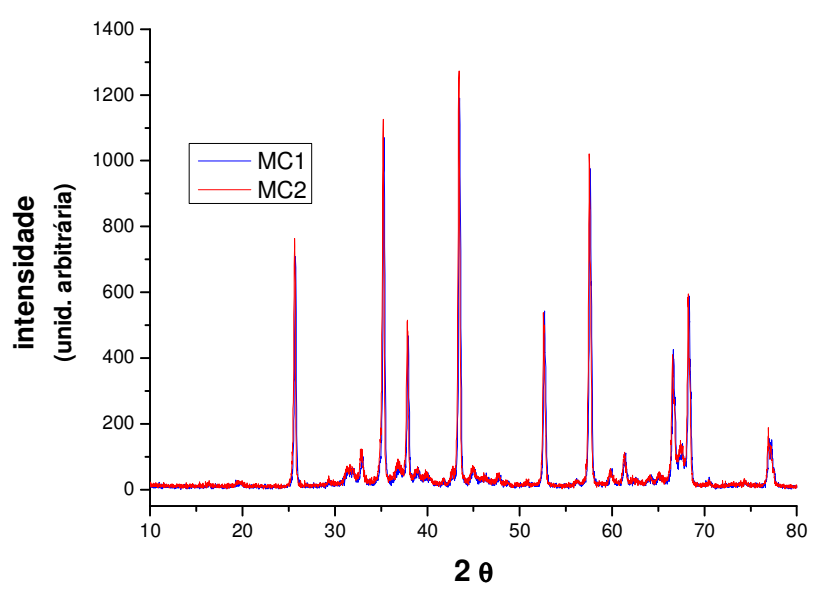

Figura 4- Difratogramas de duas amostras, lotes diferentes (MC1 e MC2) da alumina Merck calcinada pela DIRF, apresentando os picos típicos da alumina alfa.

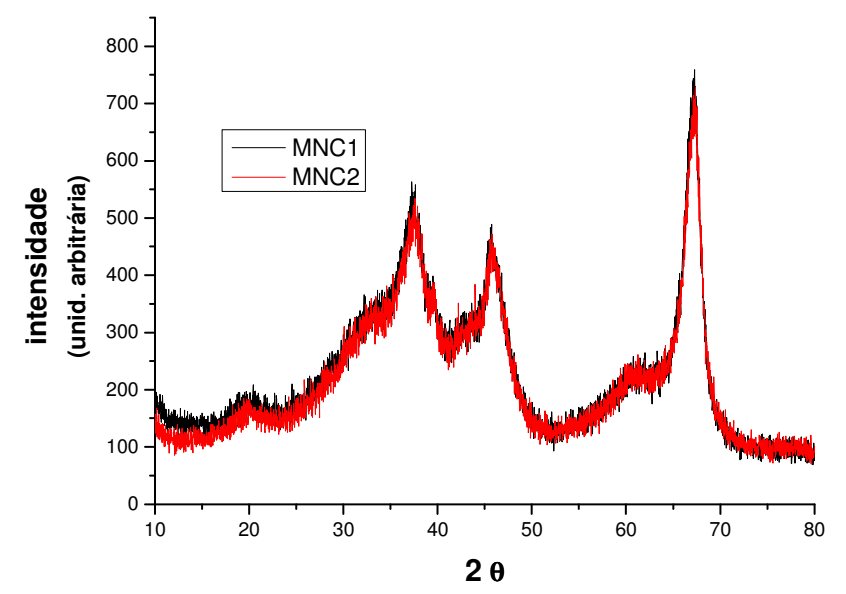

Figura 5- Difratogramas de duas amostras, diferentes lotes (MNC1 e MNC2) da alumina Merck como adquirida do fabricante, indicando picos característicos de aluminas de transição. 


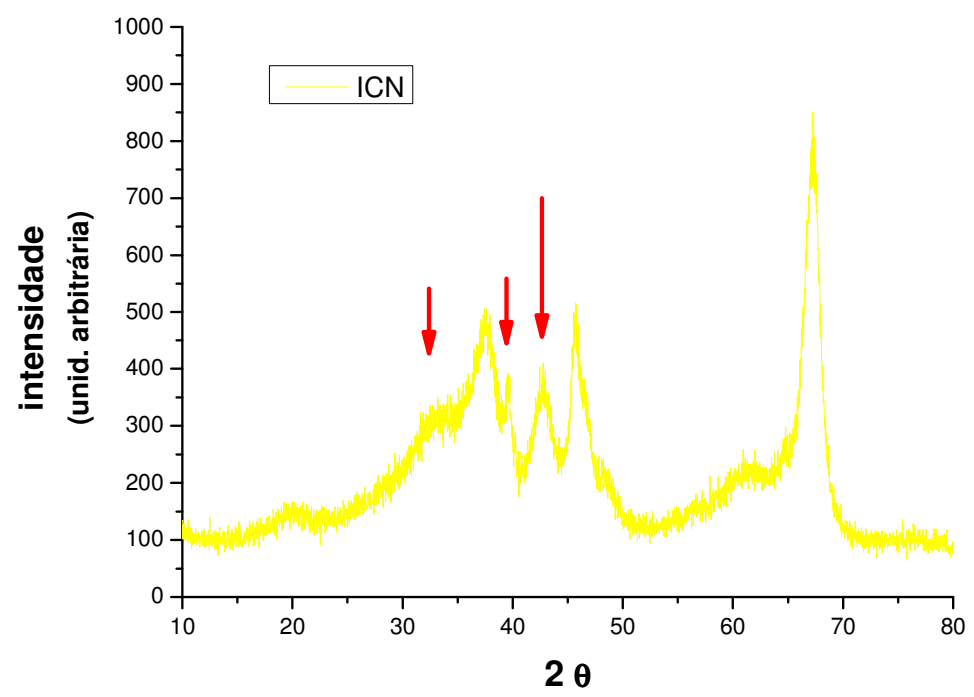

Figura 6- Difratograma da amostra de alumina ICN, indicando também picos característicos de alumina de transição. As setas indicam picos que não estão presentes nos difratogramas da alumina Merck MNC1 e MNC2, o que indica a presença de fases de transição diferentes das encontradas na alumina Merck.

Os difratogramas obtidos para as aluminas MNC, ICN (figuras 5 e 6 ) indicam que são aluminas de transição. Estas aluminas de transição são caracterizadas por pequeno tamanho de cristalito e elevada superfície específica. Os difratogramas indicam, no entanto que a alumina ICN contém fases de transição distintas das encontradas na alumina Merck.

$\mathrm{Na}$ figura 7 são comparados os difratogramas das aluminas MNC e ICN. Os dois picos que diferenciam a alumina ICN e que são apontados na figura 7 indicam como possibilidade, que esta alumina contém a fase Chi. Como pode ser constatado pela literatura, a identificação precisa das fases presentes em uma alumina de transição não é uma tarefa simples, de modo que, com as análises disponíveis até o momento, pode-se afirmar que a alumina MNC é composta predominantemente de fase Gama, enquanto a alumina ICN contem as fases Chi, Gama, e possivelmente Kappa.

Um estudo mais detalhado para determinar com maior precisão as fases de transição presentes nestas aluminas analisadas seria importante, já que estas diferentes estruturas cristalinas podem interferir significativamente no 
desempenho da alumina durante a etapa de eluição. No entanto este estudo fugiria do objetivo deste trabalho.

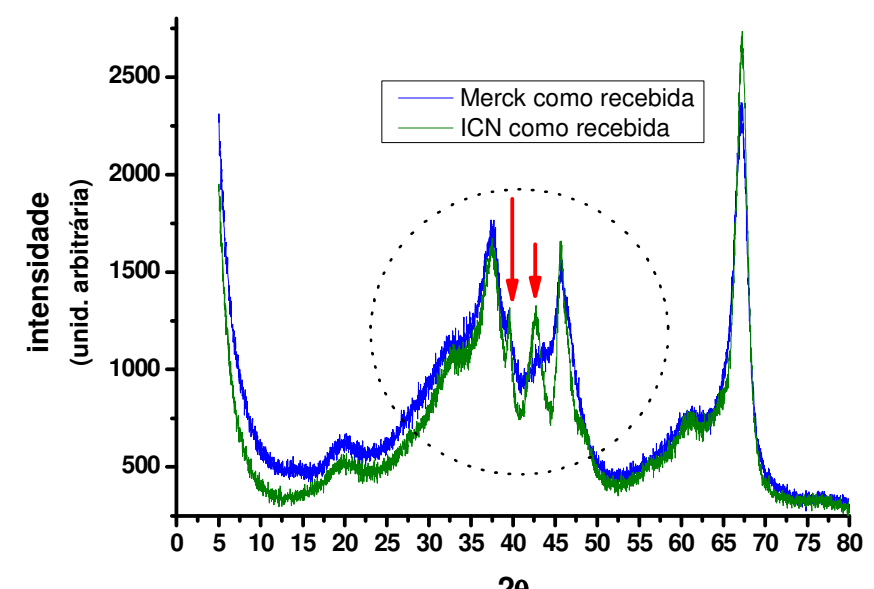

(a)

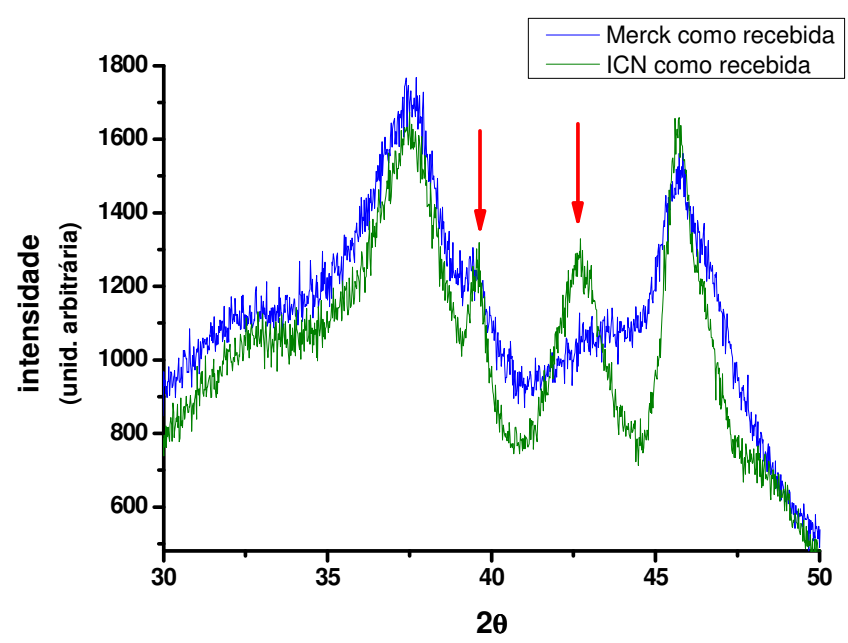

(b)

Figura 7- Difratogramas das aluminas MNC e ICN. Em (b) é apresentado detalhe dos difratogramas, indicando a diferença entre estes. 


\section{5 - 1 - 3 Distribuição de tamanho de aglomerados}

$\mathrm{Na}$ figura 8 são apresentadas as distribuições de tamanho de aglomerados das aluminas MC, MNC e ICN obtidas pela técnica de espalhamento de laser (Cilas 1064). Os pós foram analisados como recebidos, sem que houvesse uma etapa de desaglomeração. Pode-se constatar que aglomerados das três aluminas apresentam distribuição de tamanho muito semelhante, entre 230 e $50 \mu \mathrm{m}$, sendo o valor de tamanho médio de aglomerados também muito próximos (110 $\mu \mathrm{m}$ para alumina MNC e $121 \mu \mathrm{m}$ para as aluminas MC e ICN).
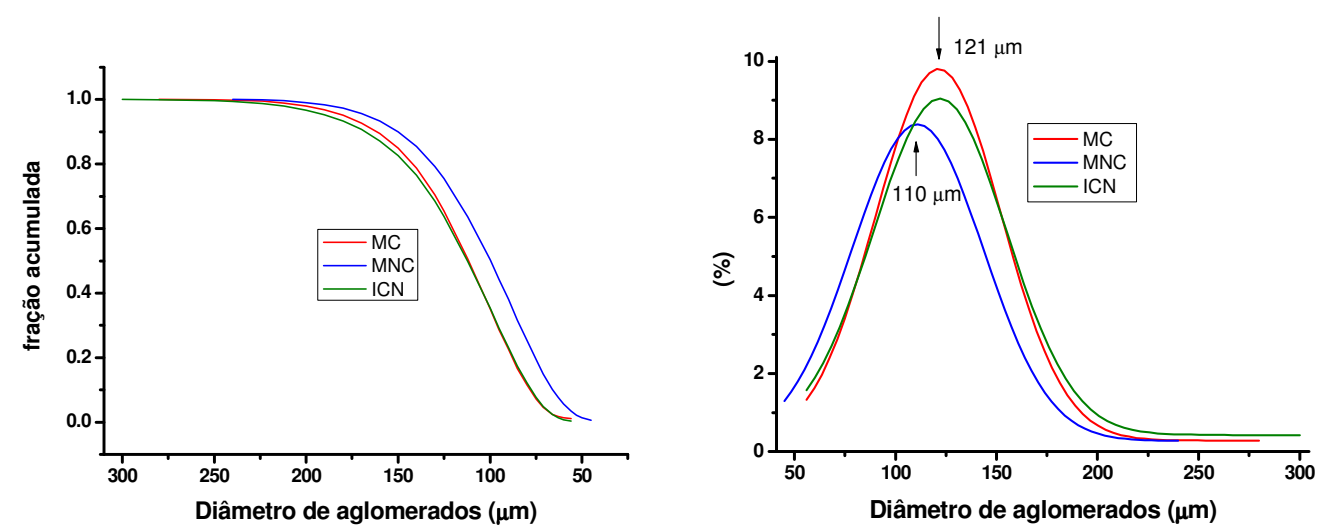

Figura 8 - Distribuição de tamanhos de aglomerados das aluminas MC, MNC e ICN.

\section{5 - 1 - 4 Micrografias dos aglomerados}

$\mathrm{Na}$ figura 9 pode-se observar micrografias obtidas por microscopia eletrônica de varredura dos aglomerados analisados. Pode-se observar que em termos de tamanho e textura, não há diferenças significativas entre as aluminas Merck e ICN.

\section{5 - 1 - 5 Superfície específica das aluminas comerciais}

$\mathrm{Na}$ Tabela IV são apresentados os valores de área de superfície específica, obtidos pelo método BET (ASAP2000 da Micromeritics Instrument Corporation). Estes dados são apresentados também na figura 10, podendo-se comparar a evolução das duas aluminas. Constata-se que sob as condições analisadas, a 
alumina Merck apresentou valores maiores de superfície específica que a alumina ICN.

\section{5 - 1 - 6 Transformação das fases das aluminas comerciais}

As aluminas tratadas termicamente foram analisadas por difração de raios $X$ para determinação das fases cristalinas presentes. Na figura 11 são apresentados os difratogramas obtidos, com as intensidades de pico normatizadas, para ambas aluminas, como recebidas e em todos os tratamentos térmicos realizados, podendo-se avaliar a evolução das fases e da cristalinidade com o tratamento, assim como comparar os comportamentos das mesmas. Observa-se que há uma diferença de fases entre as aluminas já na condição de como recebidas. Essa diferença, como já discutida anteriormente, possivelmente esteja relacionada à presença das fases Chi, Gama e possivelmente Kappa na alumina ICN, enquanto a alumina Merck teria preponderantemente fase Gama. De todo modo reafirma-se que há a dificuldade de se identificar as fases de transição da alumina, e que seria necessário um estudo mais rigoroso e prolongado para tanto. 
Tabela IV - Área de superfície específica das aluminas estudadas, com o tratamento térmico.

\begin{tabular}{|c|c|c|c|}
\hline \multicolumn{2}{|c|}{ Tratamento térmico } & \multirow{2}{*}{$\begin{array}{c}\text { Merck } \\
\mathrm{BET}\left(\mathrm{m}^{2} / \mathrm{g}\right)\end{array}$} & \multirow{2}{*}{$\begin{array}{c}\text { ICN } \\
\text { BET }\left(\mathrm{m}^{2} / \mathrm{g}\right)\end{array}$} \\
\hline Temperatura $\left({ }^{\circ} \mathrm{C}\right)$ & Tempo (horas) & & \\
\hline Original & & 178,7 & 125,1 \\
\hline \multirow[t]{2}{*}{700} & 1 & 140,4 & 113,5 \\
\hline & 6 & 127,7 & 102,9 \\
\hline \multirow[t]{2}{*}{800} & 1 & 116,8 & 100,5 \\
\hline & 6 & 105,3 & 86,6 \\
\hline \multirow[t]{2}{*}{900} & 1 & 96,4 & 76,8 \\
\hline & 6 & 78,0 & 43,5 \\
\hline \multirow[t]{2}{*}{1000} & 1 & 62,6 & 25,7 \\
\hline & 6 & 28,1 & 23,8 \\
\hline \multirow[t]{2}{*}{1100} & 1 & 22,6 & - \\
\hline & 6 & 10,6 & 7,2 \\
\hline \multirow[t]{2}{*}{1200} & 1 & 9,6 & 7,6 \\
\hline & 6 & 7,5 & 5,5 \\
\hline Calcinada DIRF & & 14,1 & \\
\hline
\end{tabular}



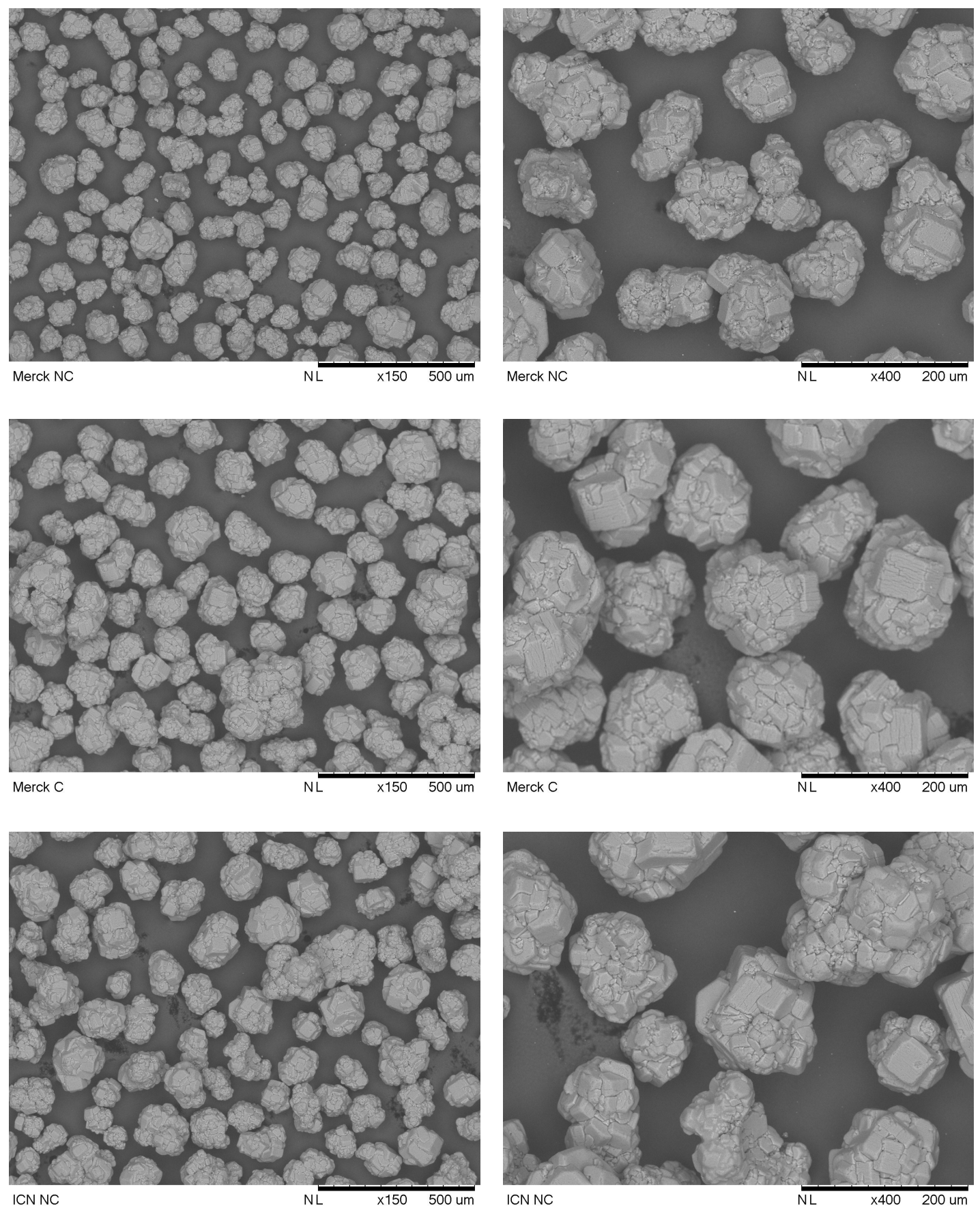

Figura 9 - Microscopia Eletrônica de Varredura (MEV) das aluminas Merck calcinada (MC), Merck não calcinada (MNC) e ICN não calcinada (ICN NC). 


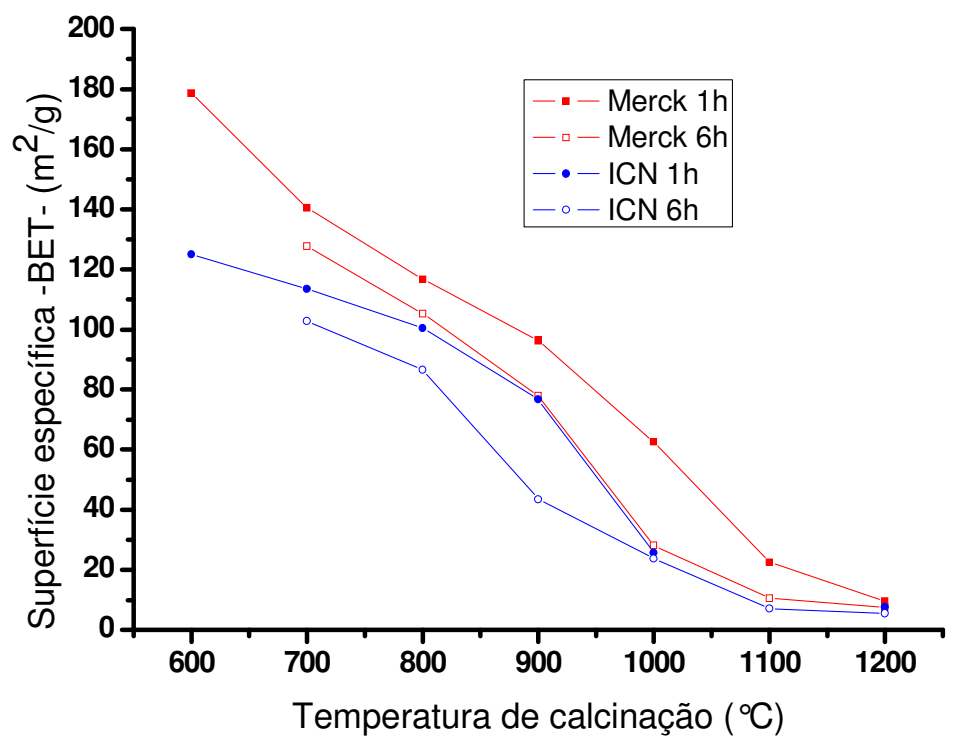

Figura 10 - Área de superfície específica das aluminas estudadas, em função do tratamento térmico.
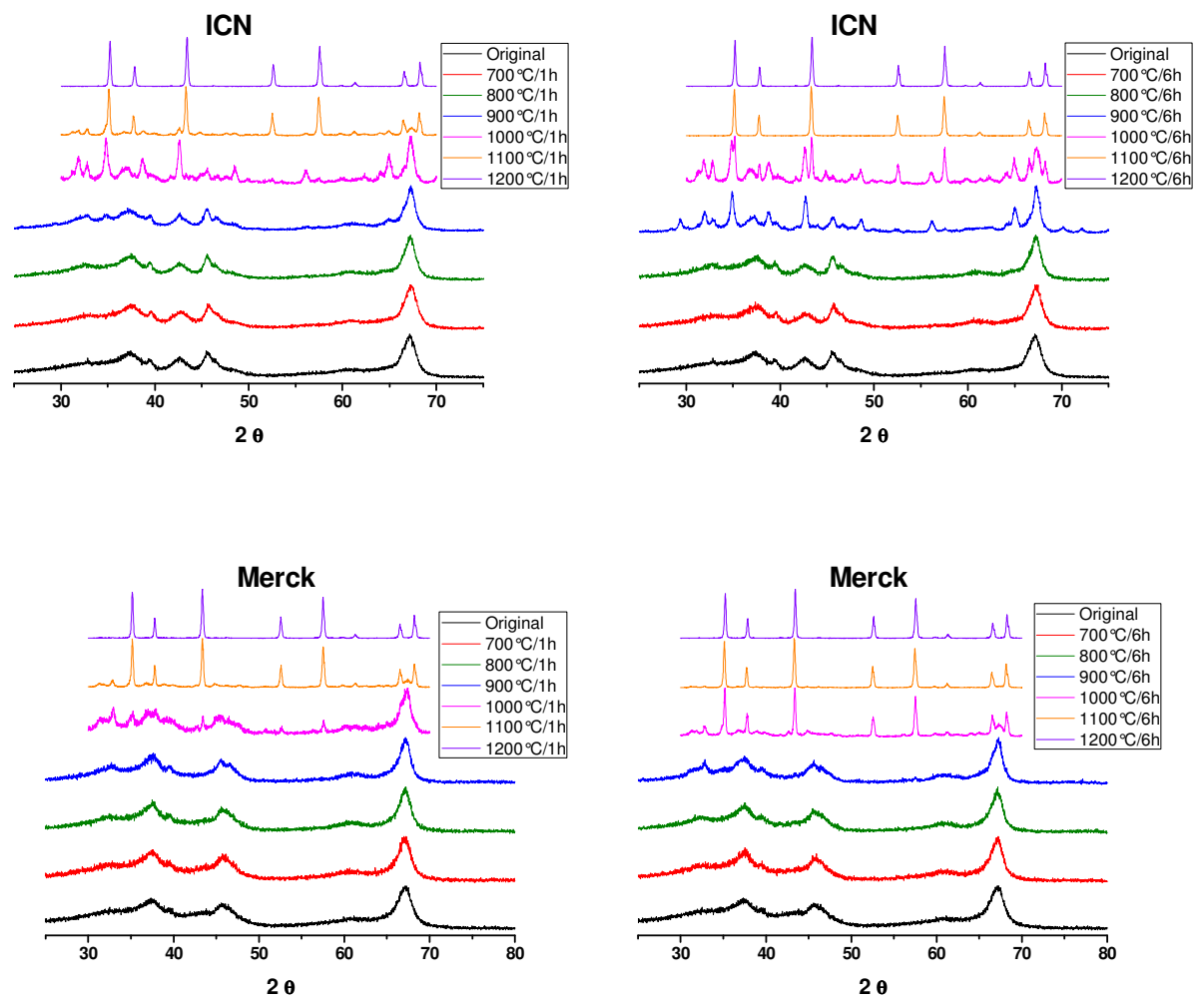

Figura 11 - Evolução das fases cristalinas, detectadas por difração de raios $\mathrm{X}$, das aluminas ICN e Merck tratadas termicamente sob diferentes temperaturas (de $700 \stackrel{\circ}{\circ}$ a $1200^{\circ} \mathrm{C}$ ) e tempos de patamar (1 ou 6 horas). 
Analisando-se a evolução das fases pode-se constatar que o pico que aparece na alumina ICN (destacado com uma seta na Figura 12), é referente à fase kappa, o que pode ser melhor visualizado após tratamento a $900{ }^{\circ} \mathrm{C}$ por 6 horas (Figura 13) quando a diferença de fases se torna mais evidente.

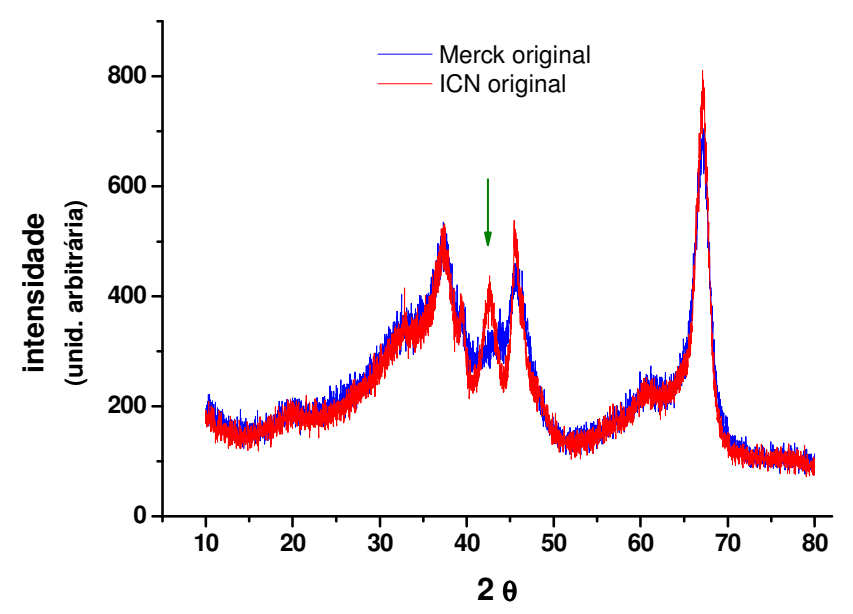

Figura 12 - Difratogramas de raios X das aluminas Merck e ICN, como recebidas.

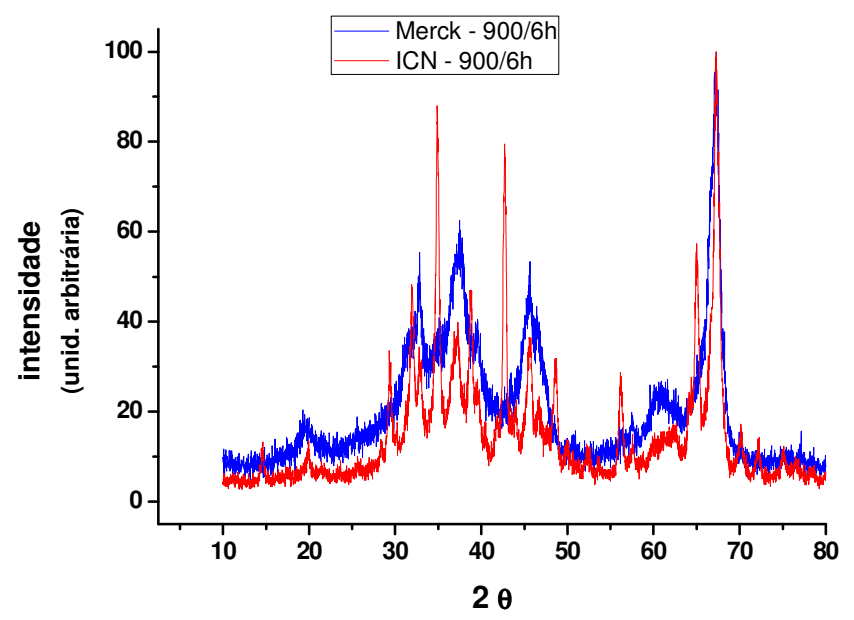

Figura 13 - Difratogramas de raios $\mathrm{X}$ das aluminas Merck e ICN, após tratamento a $900{ }^{\circ} \mathrm{C}$ por 6 horas.

$\mathrm{Na}$ Figura 14 são apresentados os difratogramas das duas aluminas tratadas a $1200{ }^{\circ} \mathrm{C}$ por uma hora, observando-se que ocorreu a completa transformação para a fase alfa. 


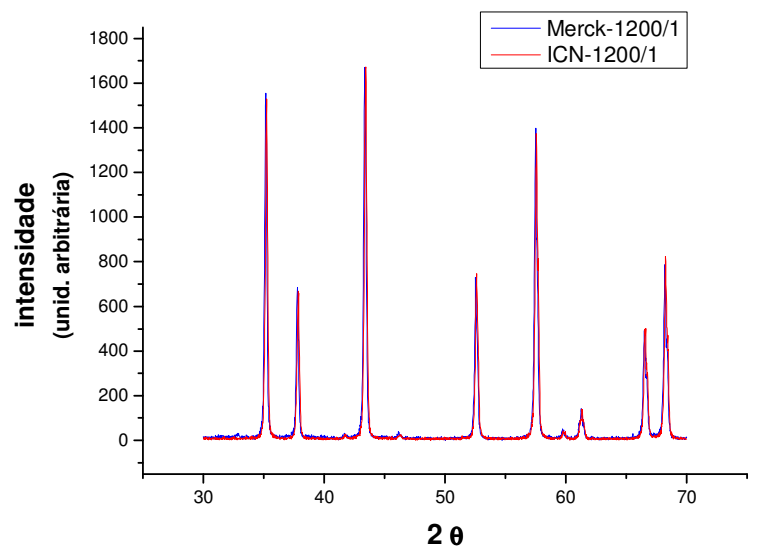

Figura 14 - Difratogramas de raios X das aluminas Merck e ICN, após tratamento térmico a $1200{ }^{\circ} \mathrm{C}$ por 1 hora, mostrando que ambas se encontram na fase alfa.

\section{5 - 2 CARACTERIZAÇÃO DAS MICROESFERAS DE ALUMINA}

\section{5 - 2 - 1 Curvas de perda de massa por análise termogravimétrica}

$\mathrm{Na}$ figura 15 são apresentadas as curvas de perda de massa, por análise termogravimétrica, de microesferas (composição C) após os diferentes testes de lavagem já descritos.

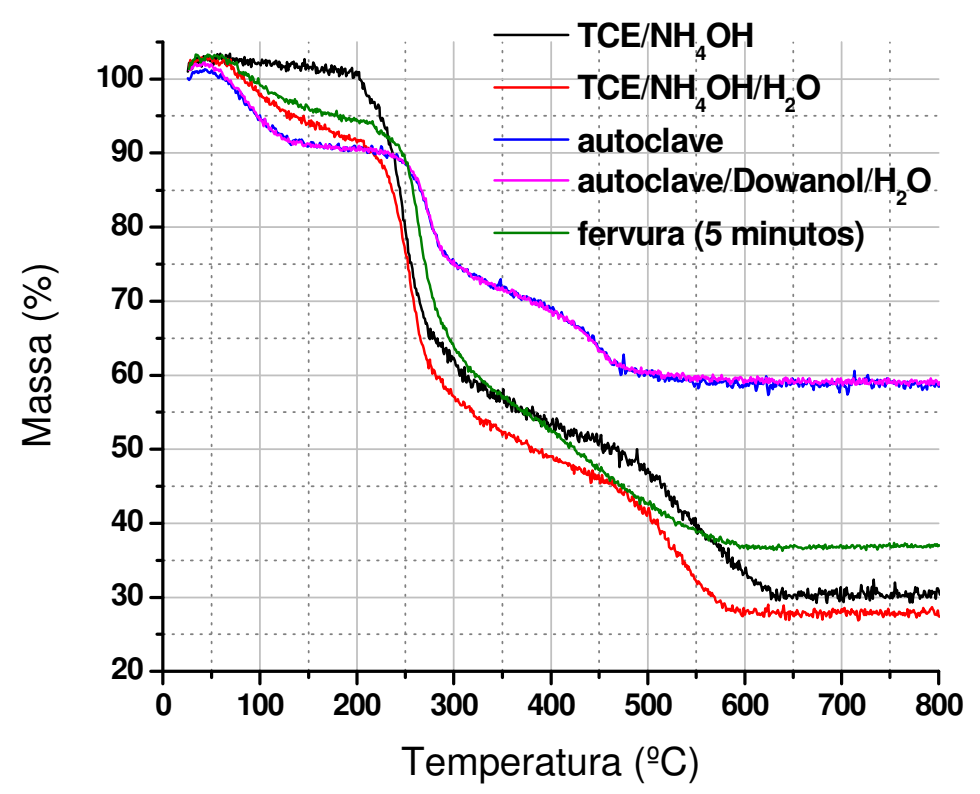

Figura 15 - Análise termogravimétrica de microesferas de composição $C$, lavadas por diferentes métodos. 
O objetivo destes experimentos foi definir um método que permitisse retirar, na etapa de lavagem, o máximo de fase orgânica; dessa forma, restando menos material para ser retirado durante o tratamento térmico (calcinação), espera-se eliminar ou minimizar o surgimento de trincas nas microesferas. Observa-se que até temperaturas próximas a $250 \stackrel{\circ}{\circ} \mathrm{C}$ as microesferas de todos os experimentos sofreram uma perda de massa de aproximadamente 10\%, que pode ser relacionada à perda de água adsorvida e estrutural. É interessante comparar o comportamento inicial das amostras lavadas apenas com TCE/ $/ \mathrm{NH}_{4} \mathrm{OH}$ com o das amostras lavadas com $\mathrm{TCE} / \mathrm{NH}_{4} \mathrm{OH} / \mathrm{H}_{2} \mathrm{O}$. As primeiras, que não foram lavadas com $\mathrm{H}_{2} \mathrm{O}$, não sofrem perda de massa antes de temperaturas próximas a $200{ }^{\circ} \mathrm{C}$, diferente das segundas que perdem água adsorvida entre 100 e $200{ }^{\circ} \mathrm{C}$. Acima de $250{ }^{\circ} \mathrm{C}$ há a eliminação da fase orgânica resultante das reações do HMTA e uréia durante a gelificação interna. As microesferas lavadas na sequência tradicional (TCE, solução diluída de $\mathrm{NH}_{4} \mathrm{OH}$ e água destilada) tiveram, durante a calcinação, perda total de massa de $70 \%$, enquanto que as microesferas tratadas em autoclave tiveram $40 \%$ de perda de massa. Isto significa que o tratamento em autoclave proporcionou a extração de $30 \%$ do peso inicial das microesferas, sendo este percentual correspondente à fase orgânica dissolvida na água, durante $o$ tratamento na autoclave. A figura permite que se dividam as curvas de perda de massa em três grupos: as correspondentes às microesferas que foram apenas lavadas da forma tradicional (com perda de massa em torno de $70 \%$ ), às microesferas que passaram pelo tratamento em autoclave (com perda de massa de $40 \%$ ), e por último a curva que passou pelo tratamento de fervura (perda de $63 \%$ ). Tem-se, portanto que o tratamento em autoclave foi o mais eficiente, proporcionando, na sequência, menor perda de massa durante a calcinação. Observou-se ainda que, diferente do esperado pela literatura, a posterior lavagem com Dowanol-PM não interferiu na perda de massa das microesferas. Observouse também que a fervura das microesferas, mesmo por 5 minutos, contribuiu para a retirada da fase orgânica (ao menos $15 \%$ da massa inicial).

Uma observação mais detalhada das curvas de perda de massa permite também constatar que há um perfil característico das mesmas: de um modo geral, para as microesferas que foram apenas lavadas, entre 250 e $300{ }^{\circ} \mathrm{C}$ há uma elevada taxa de perda de massa, que é reduzida entre 300 e $500^{\circ} \mathrm{C}$, voltando a 
aumentar entre 500 e $600 \stackrel{\circ}{\circ}$, quando atinge a estabilidade, não ocorrendo mais perda de massa. Para as microesferas submetidas à autoclave, observa-se perfil semelhante, mas com a estabilidade quanto à perda de massa sendo obtida em temperaturas ao redor de $500 \stackrel{\circ}{\mathrm{C}}$.

A partir dos resultados descritos acima optou-se por explorar os tratamentos de autoclavagem e de fervura, variando-se o número de vezes e o tempo de tratamento, e descartar o uso do Dowanol-PM. Para todos os tratamentos foi mantida fixa a relação entre a massa de água e a massa de microesferas tratadas, de 4:1. Com esta relação fixa foi possível monitorar a eficiência do processo de extração de orgânicos por meio da medida da condutividade elétrica da água após cada etapa do tratamento. A condutividade elétrica do banho é modificada pela quantidade de íons dissolvidos e assim, quanto maior a condutividade elétrica, maior a quantidade de orgânicos extraídos e dissolvidos.

Na figura 16 são apresentadas curvas de perda de massa de microesferas que, após lavagem com TCE, $\mathrm{NH}_{4} \mathrm{OH}$, e $\mathrm{H}_{2} \mathrm{O}$, passaram por tratamento em autoclave (até 5 tratamentos de $60 \mathrm{~min}$. imersas em água destilada) ou fervura, quando variou-se o número de tratamentos (até 5 fervuras por $10 \mathrm{~min}$.) ou o tempo de fervura (por até $20 \mathrm{~min}$.). Após cada tratamento (fervura ou autoclavagem) a água foi trocada, sendo medida a condutividade elétrica antes e após cada tratamento.

Pelas curvas apresentadas na figura 16 pode-se confirmar que 0 tratamento em autoclave é realmente bastante eficiente para a dissolução dos orgânicos: com apenas um tratamento de autoclavagem por 60 min., a perda de massa com o aquecimento é reduzida de $60 \%$ para $30 \%$. A diferença corresponde à quantidade de orgânico dissolvido durante o tratamento na autoclave. Constatase que o aumento no número de autoclavagens não afeta significativamente as curvas de perda de massa, indicando que com um tratamento já se atinge praticamente o limite máximo de extração de fase orgânica por este método. 


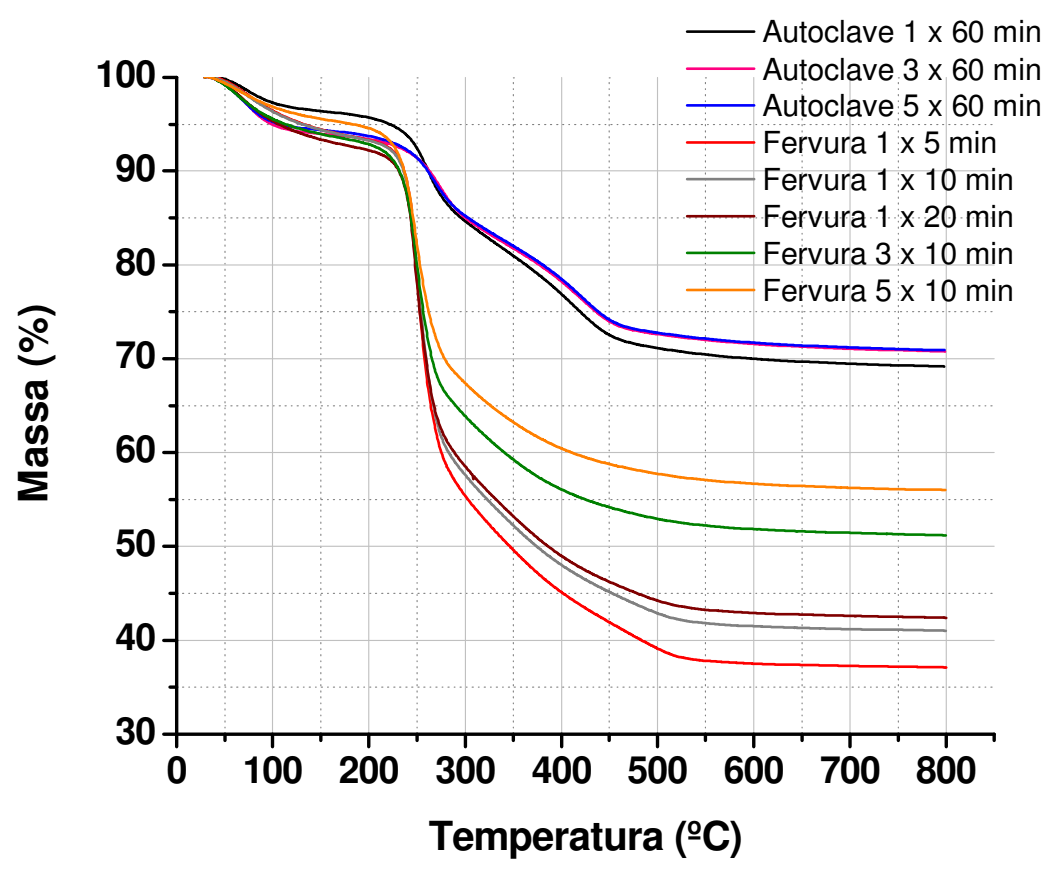

Figura 16 - Análise termogravimétrica de microesferas variando-se fervura e autoclavagem.

Quanto ao tratamento de fervura variou-se o tempo de ebulição (5, 10 e 20 min.) e o número de tratamentos consecutivos de ebulição por 10 min. Observase, quanto ao tempo de ebulição que, dobrando-se de 10 para 20 min., não ocorreu um aumento expressivo de extração dos orgânicos, indicando que 10 min. é um tempo adequado para a extração dos orgânicos com a relação água/esferas empregada. Diante disso foram realizados seguidos tratamentos de fervura (ebulição por $10 \mathrm{~min}$.) com o objetivo de se determinar o limite máximo de extração dos orgânicos por esse método. Observa-se um contínuo aumento de extração de orgânicos com 0 número de tratamentos, sendo que após 5 tratamentos de $10 \mathrm{~min}$. restou $45 \%$ de fase orgânica e água estrutural para ser eliminadas na calcinação. Este método deverá ser mais bem explorado, com maior número de tratamentos, variando-se inclusive a relação de massa água/microesferas (que será também variada para o tratamento de autoclave).

Por fim, observa-se uma nítida diferença entre os perfis das curvas de perda de massa das amostras fervidas e tratadas em autoclave. Enquanto as amostras fervidas têm uma significativa perda de massa concentrada em torno de $250{ }^{\circ} \mathrm{C}$, as amostras submetidas à autoclave perdem massa de forma menos 
brusca e em temperaturas mais elevadas. Isto sugere que estes tratamentos promovem a extração de componentes orgânicos de forma diferenciada, ou seja, cada tratamento extrai preferencialmente determinado componente. Este é mais um tema que deve ser estudado de forma mais detalhada, já que há a possibilidade de serem empregados de forma conjunta para uma extração ainda mais eficiente.

\section{5 - 2 - 2 Condutividade elétrica das soluções após lavagem}

Na figura 17 são mostrados os valores de condutividade elétrica da água do banho após os seguidos tratamentos de fervura (10 min. de ebulição em cada) e em autoclave (60 min. em cada).

Comprova-se também por essas curvas, a eficiência do tratamento em autoclave para a extração dos orgânicos. Comparando-se com as curvas de análise térmica da figura 16, confirma-se que o primeiro tratamento em autoclave dissolve a maior parte dos orgânicos (elevada condutividade elétrica), e que após o terceiro tratamento essa dissolução é bem menor. As curvas também permitem confirmar que, comparando-se os dois tratamentos, a fervura dissolve uma quantidade menor de orgânicos, e que após a terceira fervura essa dissolução também é reduzida.

Pode-se afirmar que a medida da condutividade elétrica do banho é um método adequado para monitorar a eficiência do procedimento de extração da fase orgânica.

Na figura 18 são apresentadas curvas de análise termogravimétrica das microesferas obtidas a partir das diferentes composições estudadas neste trabalho, e após o tratamento de autoclavagem. As curvas obtidas com microesferas confeccionadas a partir das composições C, E e G apresentam perfis semelhantes apesar da diferença quanto á perda total de massa. As microesferas produzidas a partir da composição D, no entanto, com menor quantidade de água com relação à composição $C$ (tabela II), apresentaram um comportamento muito diferente, com maior perda de massa. Este comportamento não pode ser explicado simplesmente pela diferença de composição; acreditou-se inicialmente que houvesse ocorrido algum problema relacionado ao tratamento de autoclavagem. No entanto o experimento foi repetido, confirmando-se esta e as 
demais características das microesferas obtidas a partir da composição D, que serão apresentadas a seguir, e que se mostraram bastante diferentes das obtidas com as outras composições.

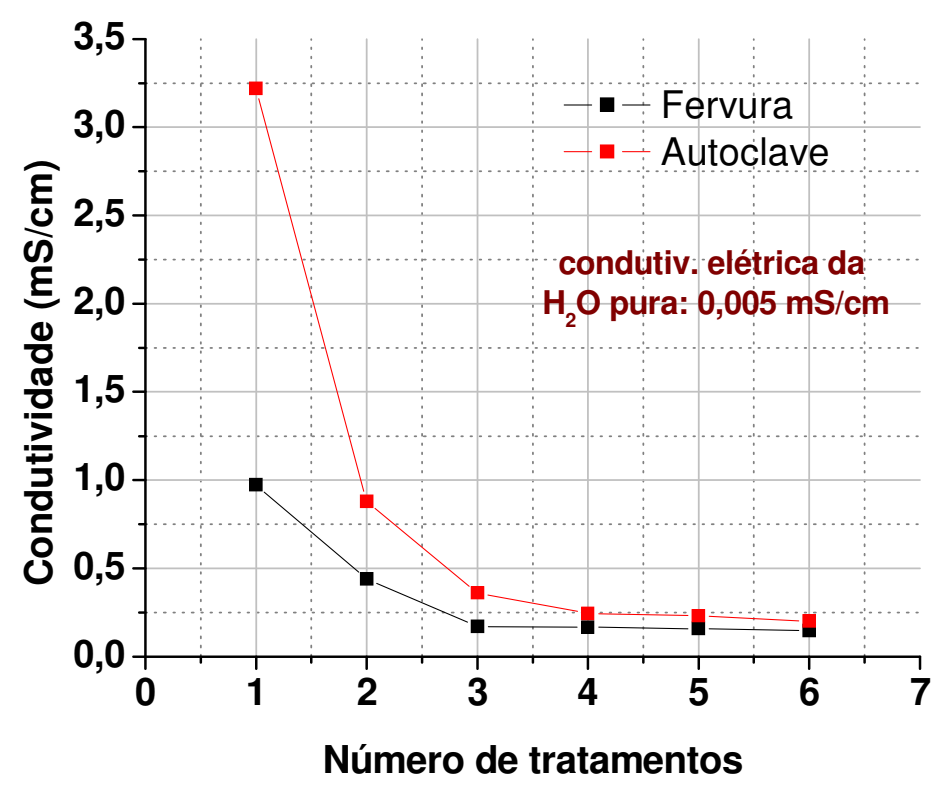

Figura 17 - Condutividade elétrica do banho após seguidos tratamentos de fervura (10 min. de ebulição) e em autoclave (1 h).

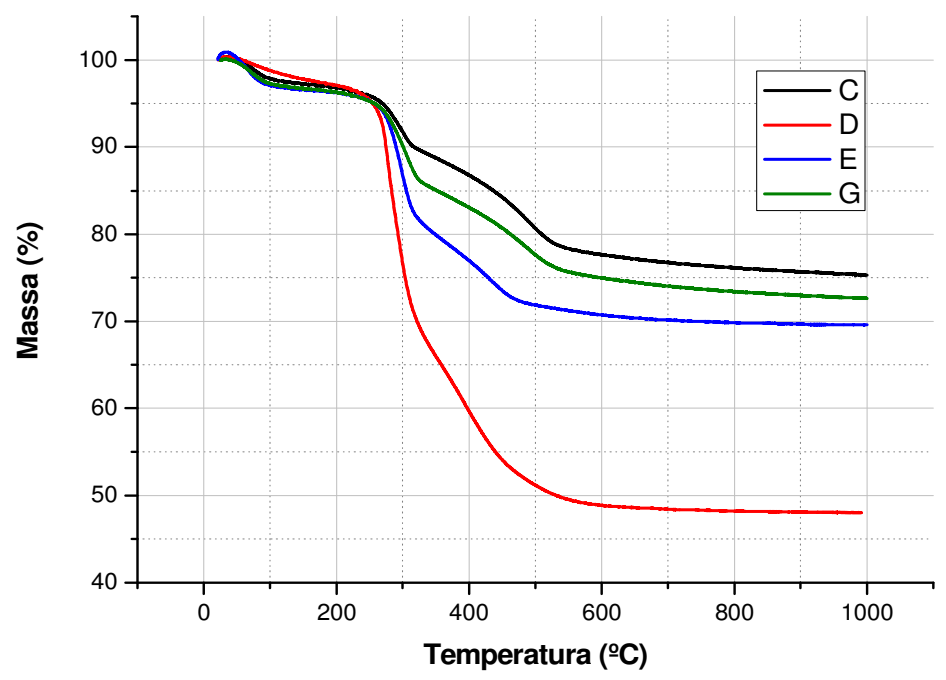

Figura 18 - Análise termogravimétrica das microesferas obtidas a partir das diferentes composições estudadas. 


\section{5 - 2 - 3 Transformação de fases com a calcinação}

$\mathrm{Na}$ figura 19 são apresentados os difratogramas de raios $\mathrm{X}$ das microesferas de composição $\mathrm{C}$, calcinadas entre 600 e $900{ }^{\circ} \mathrm{C}$.

Observa-se que há uma mudança de fases com a temperatura, sendo os difratogramas típicos das fases de transição da alumina. A identificação precisa destas fases de transição exige estudos e experimentos mais refinados, o que não faz parte dos objetivos deste estudo.

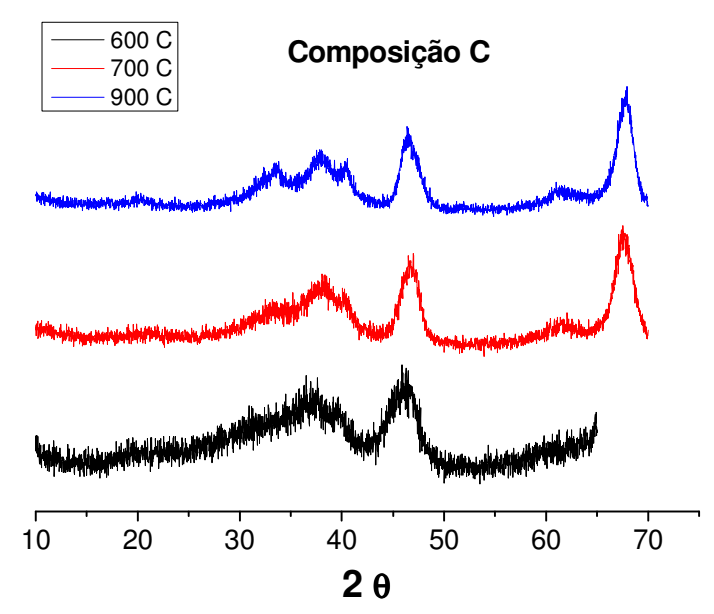

Figura 19 - Difratogramas de raios $\mathrm{X}$ das microesferas de composição $\mathrm{C}$ calcinadas a 600,700 , e $900 \stackrel{\circ}{\mathrm{C}}$ por $1 \mathrm{~h}$.

\section{5 - 2 - 4 Superfície específica e porosidade das microesferas}

$\mathrm{Na}$ tabela $\mathrm{V}$ são apresentados os valores de superfície específica, além do volume e diâmetro médio de poros para as composições estudadas, calcinadas a $700 \stackrel{\circ}{\circ}$. Observa-se que as composições E e G apresentam menores valores tanto para a superfície específica, como para volume e diâmetro médio de poros. Já a composição $C$ apresenta valores intermediários, e a composição $D$ é a que apresenta maior superfície específica, volume e diâmetro médio de poros. A tabela mostra ainda a comparação dos valores obtidos com a composição $D$ submetida a tratamento de autoclave (como as demais composições) e de fervura: constatou-se que com a fervura obteve-se microesferas calcinadas tendo maior superfície específica, volume e diâmetro médio de poros. Como não se encontrou uma justificativa para estes valores das microesferas a partir da 
composição $\mathrm{D}$, repetiu-se os experimentos, chegando-se a resultados muito similares.

Tabela V - Área de superfície específica, volume e diaâmetro dos poros para microesferas produzidas a partir de diferentes composições e condições de calcinação.

\begin{tabular}{|l|c|c|c|}
\hline Composição $-\mathrm{T}$ calcin. & $\mathrm{S}_{\mathrm{BET}}\left(\mathrm{m}^{2} / \mathrm{g}\right)$ & $\mathrm{V}_{\text {poros }}\left(\mathrm{cm}^{3} / \mathrm{g}\right)$ & $\phi_{\text {poros }}(\mathrm{A})$ \\
\hline $\mathrm{C}-700^{\circ} \mathrm{C}$ & 193 & 0,42 & 61 \\
\hline $\mathrm{D}-700^{\circ} \mathrm{C}$ autoclave & 207 & 0,68 & 131 \\
\hline $\mathrm{D}-700^{\circ} \mathrm{C}$ fervida & 222 & 0,83 & 148 \\
\hline $\mathrm{E}-700^{\circ} \mathrm{C}$ & 153 & 0,34 & 61 \\
\hline $\mathrm{G}-700^{\circ} \mathrm{C}$ & 158 & 0,38 & 55 \\
\hline
\end{tabular}

$\mathrm{Na}$ figura 20 são apresentadas as curvas de distribuição de tamanho de poros para as microesferas calcinadas a $700{ }^{\circ} \mathrm{C}$. Observa-se que a curva de distribuição de tamanho de poros da composição $D$ é muito distinta das demais curvas, em concordância com os valores apresentados na tabela $\mathrm{V}$.

$\mathrm{Na}$ figura 21 são apresentadas as curvas de adsorção/desorção para as microesferas obtidas com as diferentes composições, calcinadas a $700{ }^{\circ} \mathrm{C}$. Observa-se um comportamento bastante distinto das curvas de adsorção/desorção da composição $\mathrm{D}$, indicando entre outras coisas, um maior volume de $\mathrm{N}_{2}$ adsorvido, refletindo a maior superfície específica da mesma. Novamente tem-se que as microesferas produzidas a partir de $D$ apresentam características muito diferentes das demais também no que se refere á adsorção/desorção. 


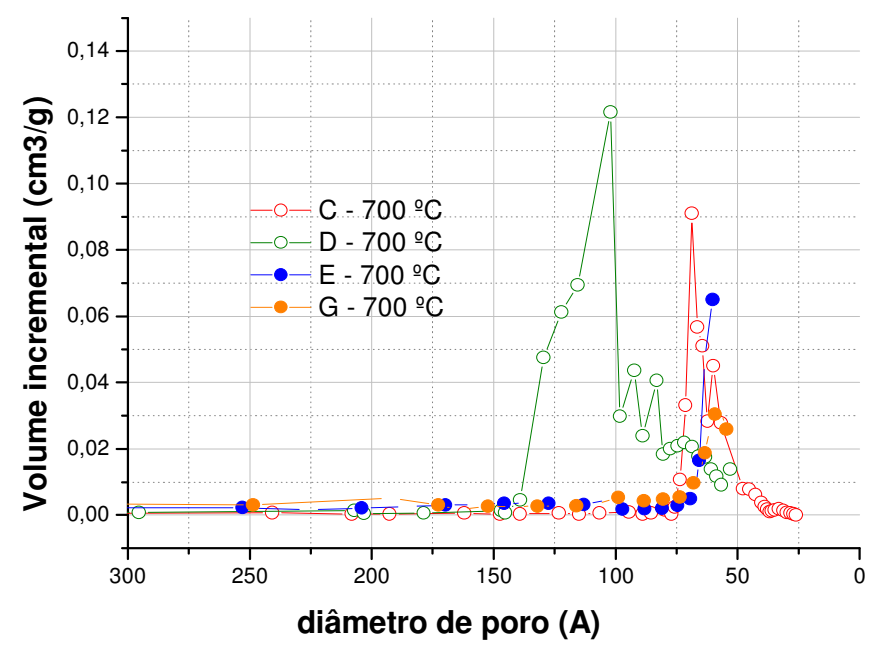

Figura 20 - Curvas de distribuição de tamanho de poros para as microesferas obtidas a partir das diferentes composições estudadas, calcinadas a $700 \stackrel{\circ}{ } \mathrm{C}$

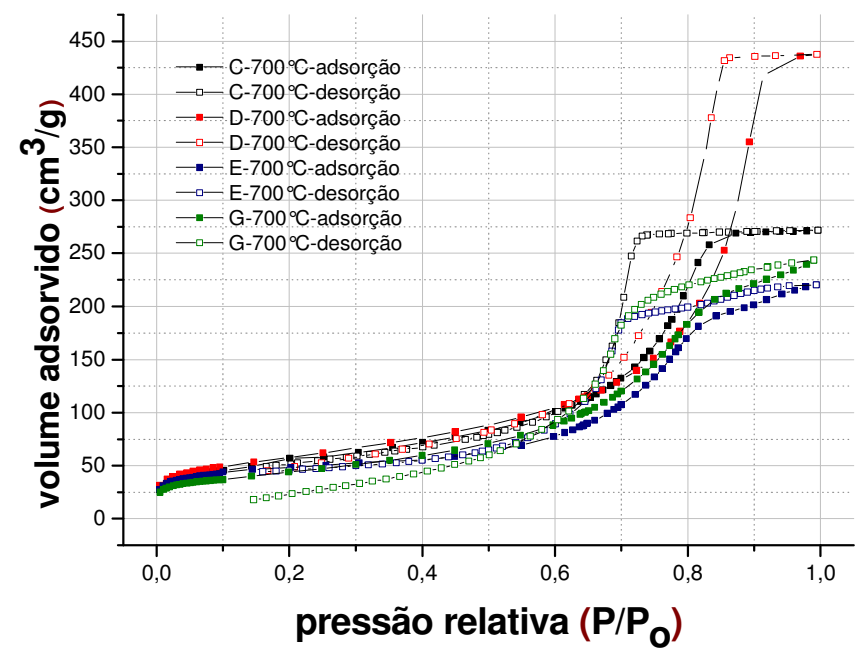

Figura 21 - Curvas de adsorção/desorção para as microesferas obtidas a partir das diferentes composições estudadas, calcinadas a $700{ }^{\circ} \mathrm{C}$.

Comparando-se os perfis das curvas de adsorção/desorção, pode-se afirmar que as microesferas obtidas a partir das composições $C$ e $D$ apresentam poros regulares tipo cilíndricos abertos ou fechados podendo apresentar estrangulamentos formando poros tipo garrafa; já as microesferas obtidas a partir de $E$ e $G$ também se mostram mesoporosas mas com poros cilíndricos abertos, e fechados com estrangulações. Além disso, pelos perfis das curvas de adsorção pode-se afirmar que apresentam morfologia tipo garrafa. As curvas referentes às 
microesferas $D$ apesar de apresentarem perfil semelhante às de $C$, se destacam pelo maior volume de gás adsorvido (volume de poros).

$\mathrm{Na}$ figura 22 são apresentadas curvas de distribuição de tamanho de poros para as microesferas da composição $\mathrm{D}$, submetidas a diferentes tratamentos na lavagem: fervura e autoclavagem. Constata-se que o tratamento interfere na porosidade final das microesferas, com a fervura proporcionando volume e tamanho médio de poros maior que a autoclavagem.

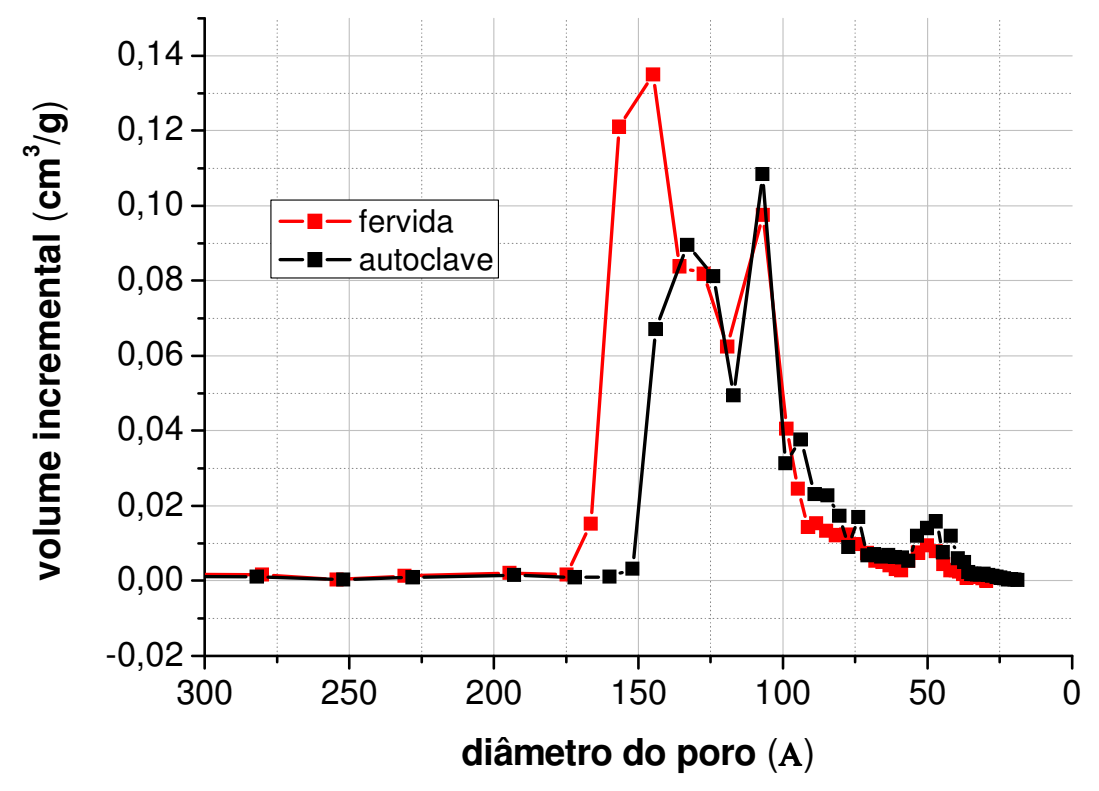

Figura 22 - Porosidade das microesferas D, (relação entre fervidas e autoclave).

A partir destes resultados definiu-se por concentrar os estudos nas composições $\mathrm{C}$ e $\mathrm{D}$, que foram calcinadas em diferentes temperaturas.

$\mathrm{Na}$ tabela VI são apresentados os valores de superfície específica juntamente com o tamanho médio e volume de poros para as microesferas obtidas a partir das composições $\mathrm{C}$ e D, calcinadas a 600,700 e $900{ }^{\circ} \mathrm{C}$ por uma hora. Comparando-se com os valores de superfície específica dos pós comerciais calcinados nas mesmas condições, tabela IV, constata-se que as microesferas possuem superfície específica consideravelmente maior que os pós comerciais, o que permite vislumbrar a possibilidade de maior adsorção de Mo na coluna de eluicão. Nas figuras 23 e 24 são apresentadas respectivamente as curvas de 
distribuição de tamanho de poros e as curvas de adsorção/desorção para estas mesmas microesferas.

Observa-se que para ambas as composições ocorre um aumento no diâmetro dos poros com o aumento da temperatura de calcinação, o que iria contra o senso comum. No entanto nesta faixa de temperatura ocorre a transformação entre as fases de transição da alumina, um aumento na cristalização, e são estas mudanças que podem explicar o aumento no tamanho médio de poros com a temperatura. Destaca-se também que a composição $D$ apresenta, em comparação à composição $\mathrm{C}$, maiores valores de tamanho médio e volume de poros para todas as temperaturas estudadas. Para as três temperaturas de calcinação, as curvas de adsorção e desorção não apresentam grandes diferenças quanto ao perfil, indicando que se trata de materiais mesoporosos, com poros regulares, de formato cilíndrico ou poliédrico e com as extremidades abertas.

Tabela VI - Área superficial, volume e tamanho dos poros para microesferas produzidas a partir de diferentes composições e condições de calcinação.

\begin{tabular}{|c|c|c|c|}
\hline Composição $-\mathrm{T}$ calcin. & $\mathrm{S}_{\mathrm{BET}}\left(\mathrm{m}^{2} / \mathrm{g}\right)$ & $\mathrm{V}_{\text {poros }}\left(\mathrm{cm}^{3} / \mathrm{g}\right)$ & $\phi_{\text {poros }}(\mathrm{A})$ \\
\hline $\mathrm{C}-600^{\circ} \mathrm{C}$ & 265 & 0,40 & 42 \\
\hline $\mathrm{C}-700^{\circ} \mathrm{C}$ & 193 & 0,42 & 61 \\
\hline $\mathrm{C}-900^{\circ} \mathrm{C}$ & 149 & 0,40 & 119 \\
\hline $\mathrm{D}-600^{\circ} \mathrm{C}$ & 228 & 0,68 & 131 \\
\hline $\mathrm{D}-700^{\circ} \mathrm{C}$ & 207 & 0,68 & 198 \\
\hline $\mathrm{D}-900^{\circ} \mathrm{C}$ & 124 & 0,61 & - \\
\hline Alumina Merck $700^{\circ} \mathrm{C}$ & 140 & - & - \\
\hline Alumina ICN $700^{\circ} \mathrm{C}$ & 113 & - & - \\
\hline Alumina Merck $900^{\circ} \mathrm{C}$ & 96 & - & - \\
\hline Alumina ICN $900^{\circ} \mathrm{C}$ & 77 & & - \\
\hline
\end{tabular}


Um dos principais pontos observado neste trabalho é a grande diferença de comportamento entre as composições $\mathrm{C}$ e $\mathrm{D}$ no que se refere à porosidade. Como a única diferença entre as duas composições é que $D$ apresenta $25 \%$ a menos de água que $\mathrm{C}$, o que a princípio, não seria uma justificativa para este comportamento.

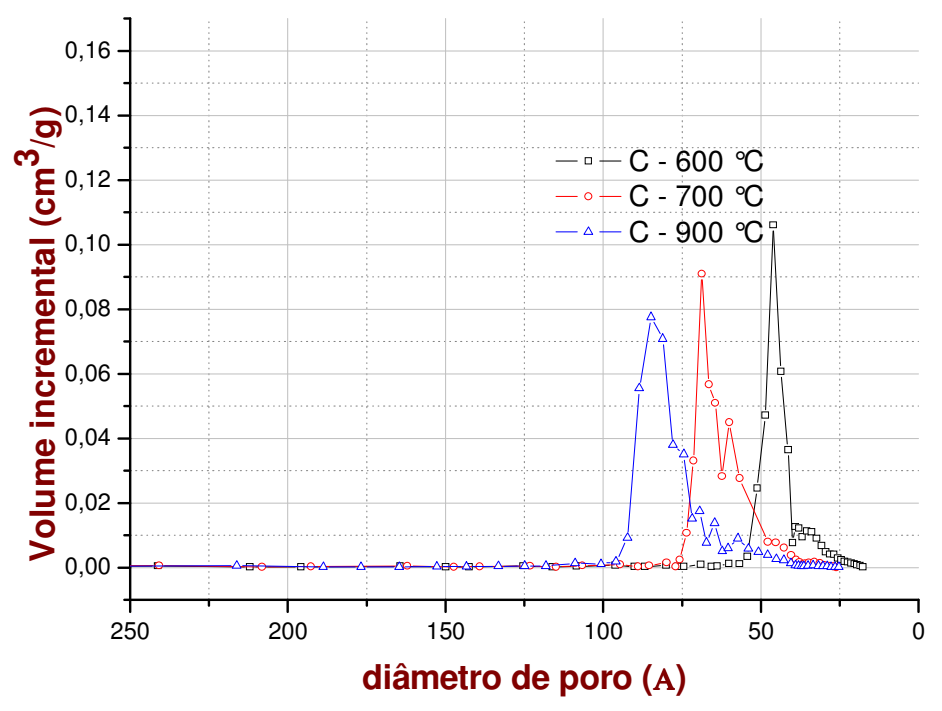

(a)

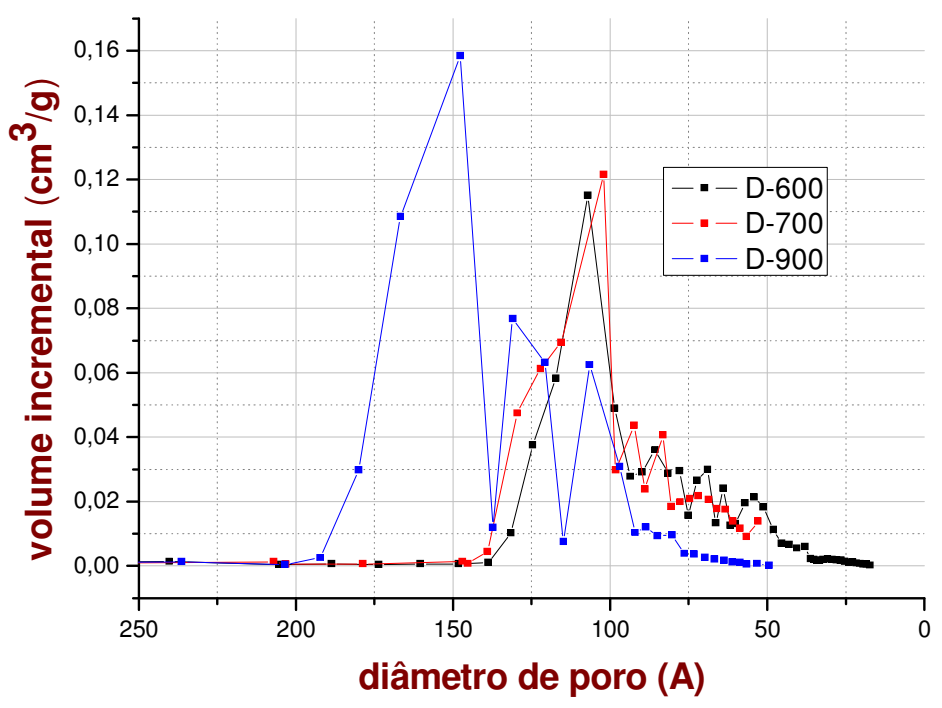

(b)

Figura 23 - Distribuição de tamanho de poros das microesferas de composição C (a) e D (b), calcinadas a diferentes temperaturas. 


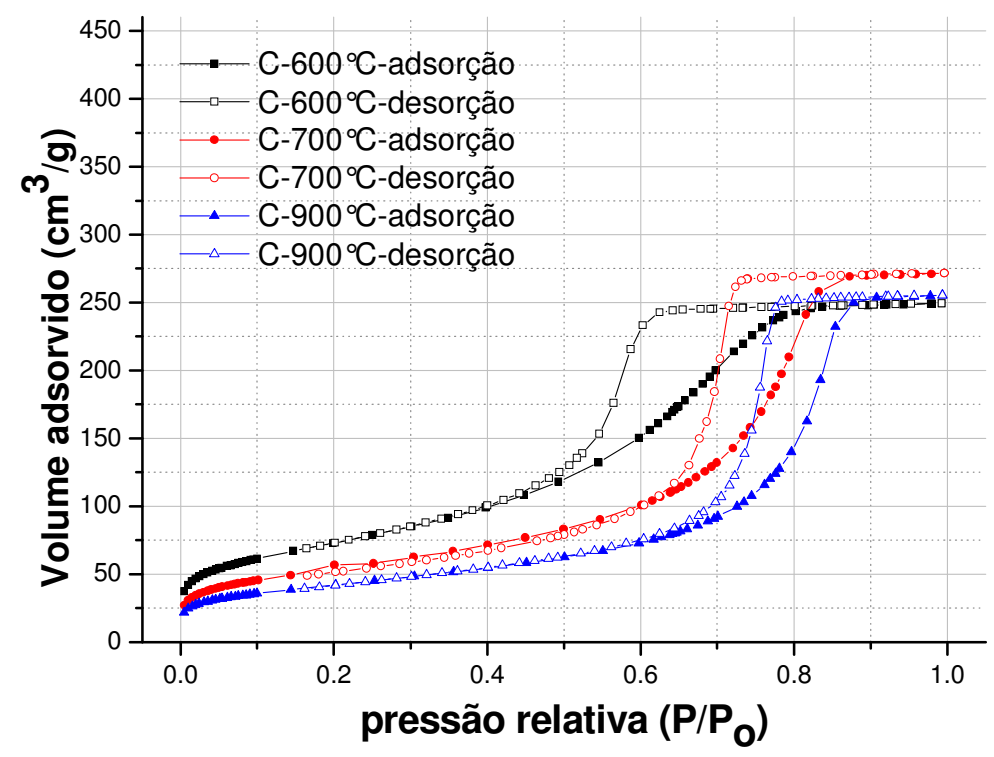

(a)

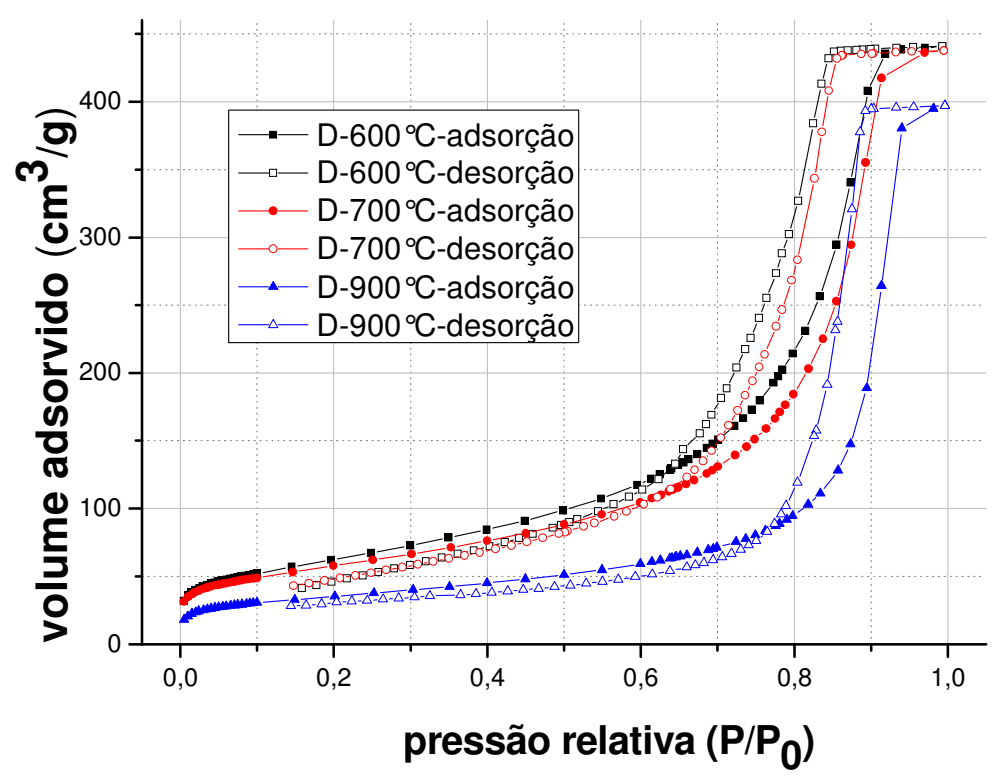

(b)

Figura 24 - Curvas de adsorção/desorção das microesferas de composição C (a) e $D(b)$, calcinadas a diferentes temperaturas. 
$\mathrm{Na}$ figura 25 é mostrada a distribuição de tamanho de microesferas da composição $\mathrm{C}$, após secagem ao ar, secagem a $110 \stackrel{\circ}{\mathrm{C}}$ e após calcinação a 700 oC. Constata-se que as microesferas não retraíram durante a secagem e calcinação, tendo, portanto curvas de distribuição de tamanho muito próximas. Nas condições em que estas microesferas foram produzidas, tiveram o diâmetro variando praticamente entre 0,4 e 1,2 mm, com diâmetro médio em torno de 0,65 $\mathrm{mm}$. O controle do tamanho das microesferas é um tema de grande interesse, pois pode ampliar as possibilidades de aplicação das mesmas. Apesar de se ter buscado formas de variação e controle do tamanho das microesferas produzidas, não se teve tempo hábil pra um estudo mais detalhado do assunto.

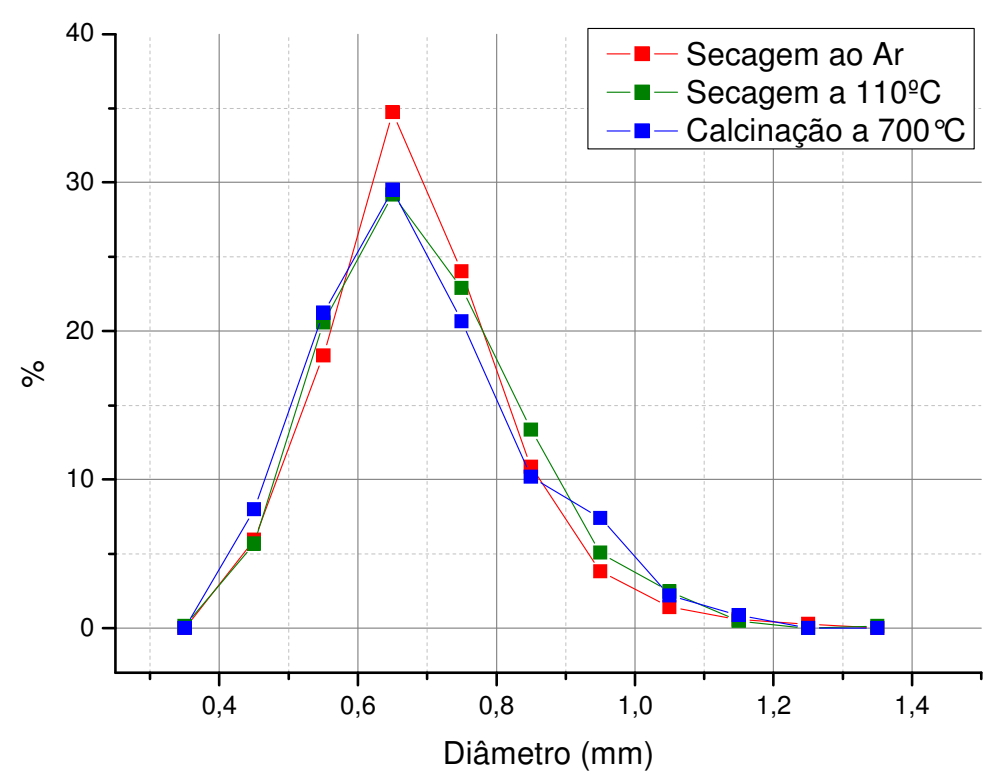

Figura 25 - Distribuição de tamanho a partir do diâmetro, das microesferas secas ao ar, em estufa e calcinadas a $700 \stackrel{\circ}{C} / 1 \mathrm{~h}$

Nas figuras 26 e 27 são apresentadas micrografias de microesferas tratadas em autoclave e fervidas, após a secagem em estufa por 24 h e após a calcinação a $700{ }^{\circ} \mathrm{C}$. Pode-se afirmar que durante a calcinação as microesferas não retraíram significativamente, pois esta retração ocorreu na etapa anterior, na secagem em estufa.

Estas figuras mostram que as microesferas tratadas nas condições especificadas, ficaram intactas, sem a presença de trincas, indicando a eficiência tanto da fervura quanto do tratamento em autoclave. 


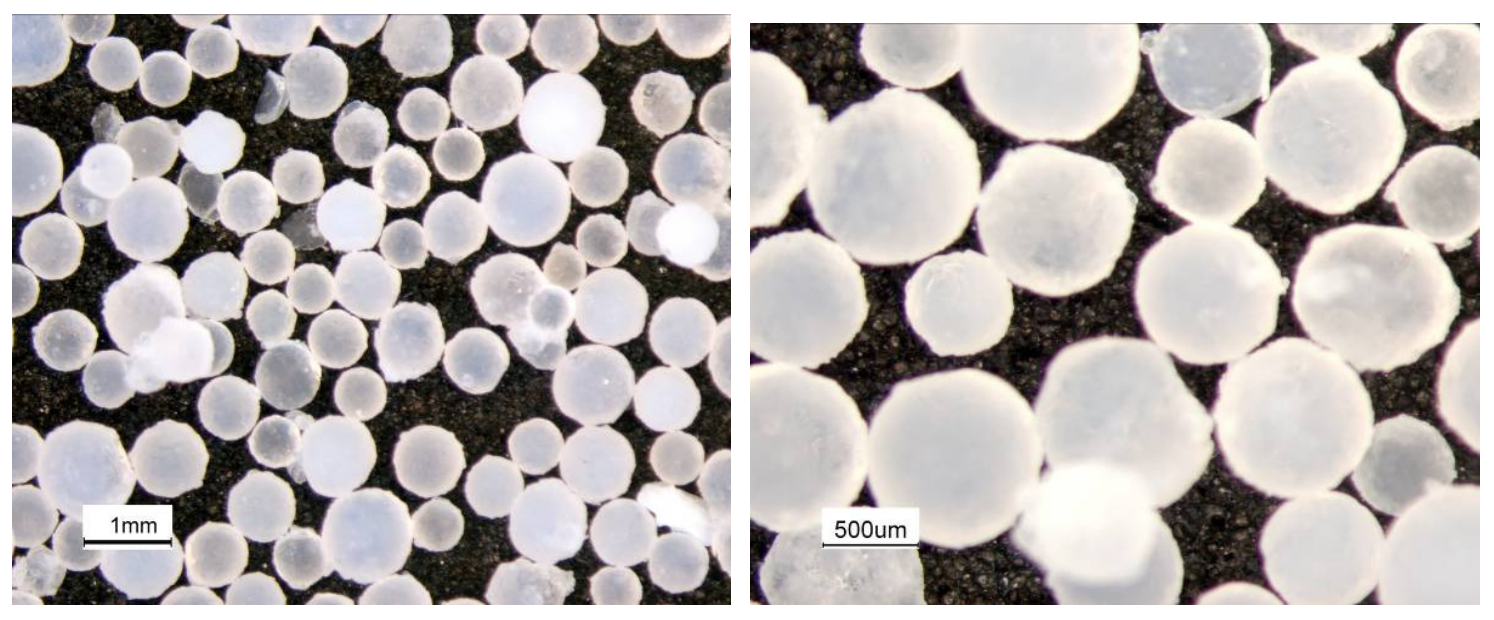

Figura 26: Microesferas tratadas em autoclave e calcinadas a $700{ }^{\circ} \mathrm{C}$ por $60 \mathrm{~min}$.

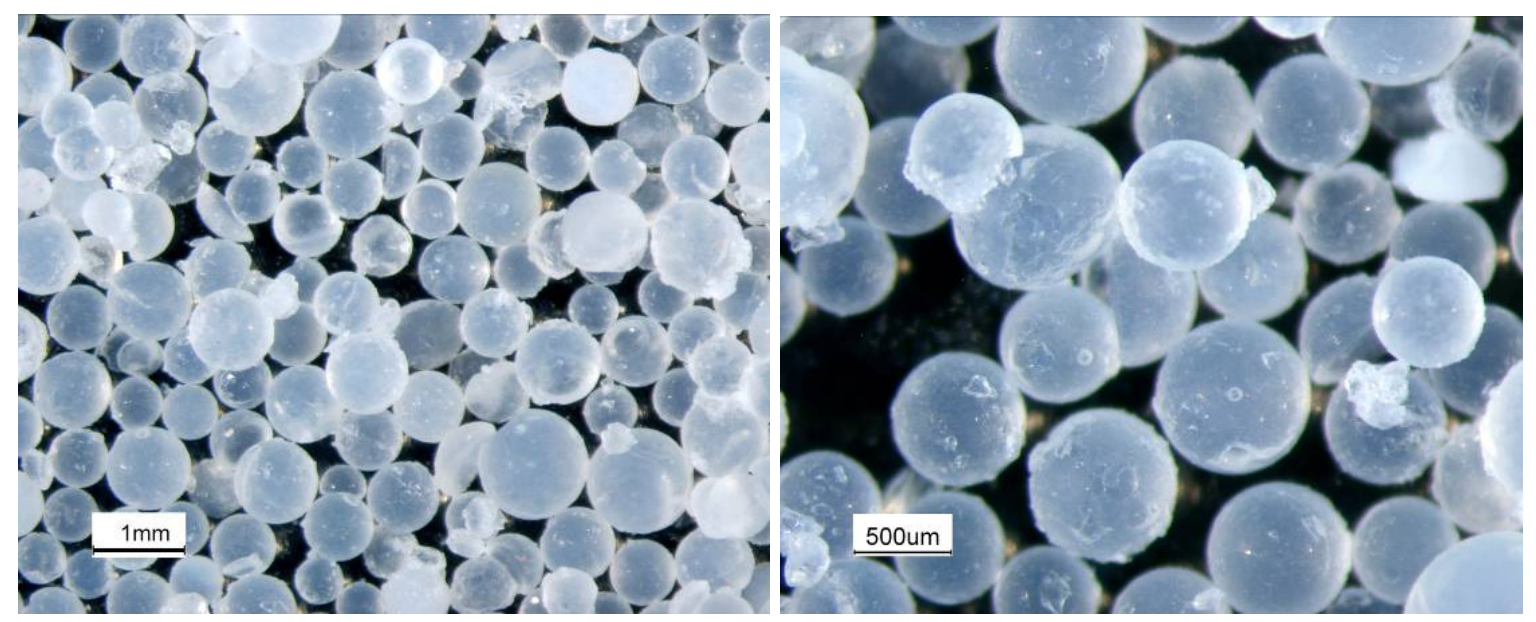

Figura 27: Microesferas tratadas em autoclave e deixadas em estufa por $24 \mathrm{~h}$.

Nas figuras 28 a 31 são apresentadas imagens de microesferas calcinadas a $700 \stackrel{\circ}{ } \mathrm{C}$, obtidas pelo microscópio eletrônico de varredura, com sensor de elétrons retro-espalhados (TM-3000 Hitachi Tabletop Microscope).

Observa-se que as microesferas obtidas com as composições C e D apresentam-se relativamente intactas, esféricas e regulares, ao passo que as microesferas obtidas a partir das composições E e G são irregulares, deformadas e com muitas trincas. 

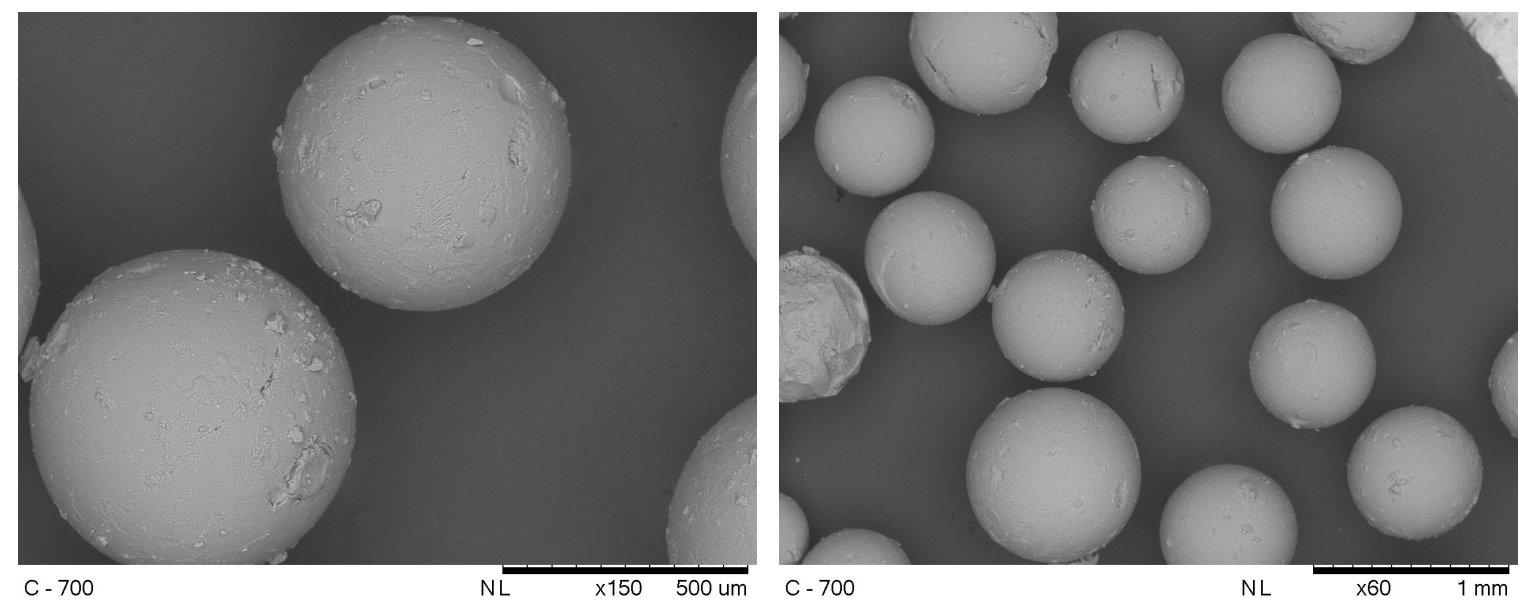

Figura 28 - Microesferas de composição $C$, calcinadas a $700 \stackrel{\circ}{-} / 1 \mathrm{~h}$.

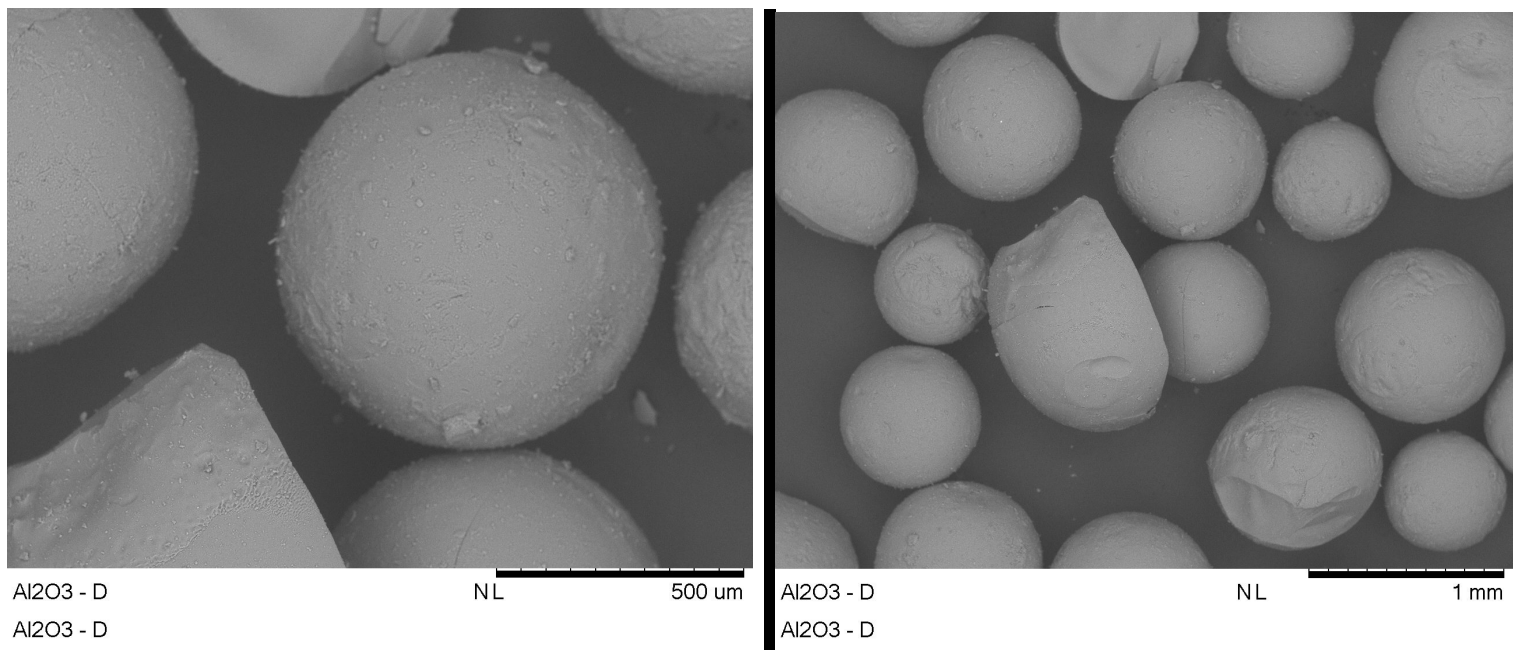

Figura 29 - Microesferas de composição $\mathrm{D}$, calcinadas a $700{ }^{\circ} \mathrm{C} / 1 \mathrm{~h}$.
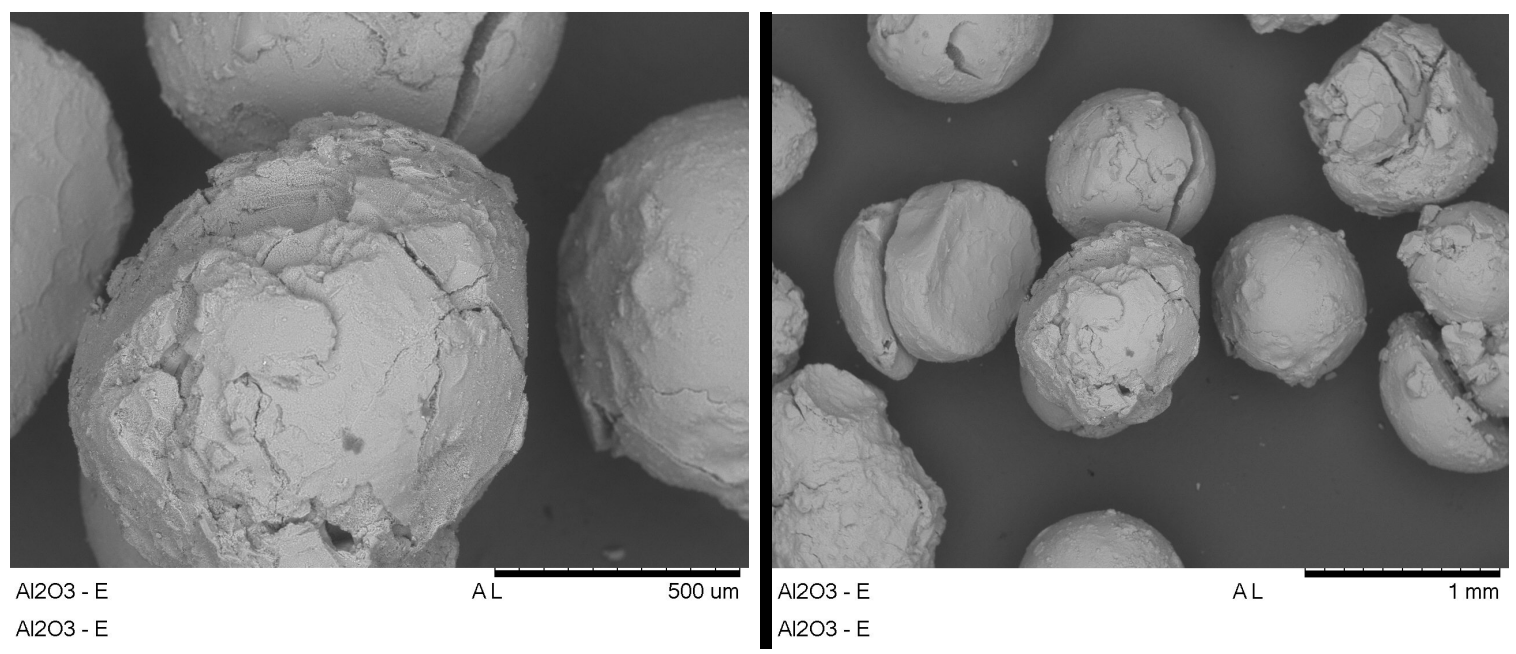

Figura 30 - Microesferas de composição E, calcinadas a $700 \stackrel{\circ}{\circ} \mathrm{C} / 1 \mathrm{~h}$. 

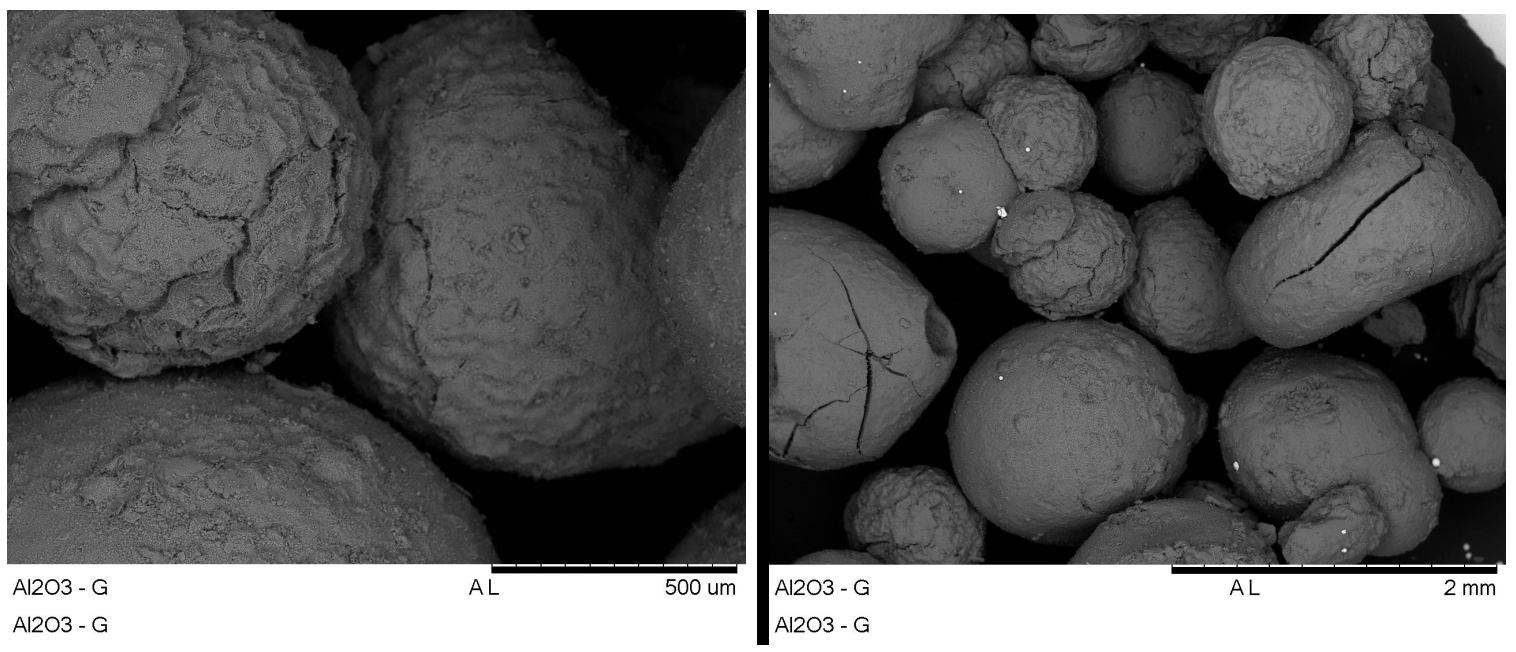

Figura 31 - Microesferas de composição G calcinadas a $700^{\circ} \mathrm{C} / 1 \mathrm{~h}$. 


\section{6 - CONCLUSÕES}

O método da gelificação interna se mostrou bastante eficiente para a confecção de microesferas de $\mathrm{Al}_{2} \mathrm{O}_{3}$ isentas de trincas.

A etapa de lavagem é o ponto fundamental na eliminação de trincas que surgem durante a calcinação. Nesta etapa deve-se extrair das microesferas o máximo possível de materiais orgânicos (produtos da reação da ureia e do HMTA), reduzindo a quantidade a ser eliminada nas etapas posteriores (secagem e principalmente calcinação).

O tratamento em autoclave foi considerado o mais eficiente para a extração da fase orgânica das microesferas. Foi possível dissolver no banho, mais que $60 \%$ da fase orgânica, restando bem menos deste material a ser eliminado na calcinação. Dessa forma evitou-se o surgimento de trincas nas microesferas antes depois de calcinadas.

A fervura também permitiu a dissolução da fase orgânica das microesferas, apesar de em menor quantidade. No entanto as microesferas fervidas apresentaram maior porosidade que as tratadas em autoclave.

A eficiência do processo de extração da fase orgânica pode ser monitorada de forma adequada pela medida da condutividade elétrica do banho, após o tratamento de lavagem (fervura ou autoclavagem).

As microesferas possuem maior superfície específica que os pós comerciais estudados, quando calcinados nas mesmas condições.

A qualidade e as características físicas das microesferas são fortemente dependentes da composição da solução inicial. Por exemplo, a composição D, com menor teor de água que a composição $\mathrm{C}$, apresentou porosidade significativamente maior. 


\section{7- REFERÊNCIAS BIBLIOGRÁFICAS}

[1] P. Naefe, and E. Zimmer, 1979, Preparation of uranium kernels by an external gelation process: Nuclear Technology, v. 42, p. 163.

[2] A. Berthold, A. Haibel, N. Brandes, L. Kroh, U. Gross, L. Uharek, and H. Schubert, 2007, Biocompatible porous ceramics for the cultivation of hematopoietic cells. Journal of Materials Science-Materials in Medicine, v. 18, p. 1333-1338.

[3] P.A. Haas, J.Pitt, S.M. Robinson and A.D. Ryon, 1983, Preparation of metal oxide gel spheres with hexamethylenetetramine as an ammonia donor: Industrial and Engineering Chemistry Product Research and Development, v. 22, p. 461-466.

[4] F. W. van der Brugghens, A. J. Noothout, M. E. A. Hermans, J. B. W. Kanij, and O. Votocek, 1970, "A U (VI)-Process for Microsphere Production," in Proc. Symp. Sol-Gel Processes and Reactor Fuel Cycles, Gatlinburg, Tennessee, CONF-700502, U.S. Atomic Energy Commission.

[5]. P. A. Haas, J. M. Begovich, A. D. Ryon, and S. J. Vavruska, 1979, Chemical Flowsheet for Preparing Urania Spheres by Internal Gelation, ORNL/TM-6850.

[6] M. H. Lloyd, J. L. Collins, R. L. Fellows, S. E. Shell, D. H. Newman, and W. B. Stines, 1983, A Gel Sphere Process for FBR Fuel Fabrication from Coprocessed Feed, ORNL/TM-8399.

[7]. J. L. Collins, M. F. Lloyd, and R. L. Fellows, 1987, "The Basic Chemistry Involved in the Internal-Gelation Method of Precipitating Uranium as Determined by pH Measurements," Radiochim. Acta 42, 121-34.

[8]. M. H. Lloyd, J. L. Collins, and S. E. Shell, 1985, "Method of Controlling Crystallite Size in Nuclear-Reactor Fuels," U.S. Patent No. 4,502,987.

[9]. J. L. Collins, R. D. Hunt, G. D. Del Cul, and D. F. Williams, 2004, Production of Depleted $\mathrm{UO}_{2}$ Kernels for the Advanced Gas-Cooled Reactor Program for Use in TRISO Coating Development, ORNL/TM-2004/123.

[10]. J. L. Collins, 2003, "Method of Preparing Hydrous Zirconium Oxide Gels and Spherules," U.S. Patent No. 6,602,919 B1. 
[11]. J. L. Collins, 1998. "Method of Preparing Hydrous Titanium Oxide Gels and Spherules," U.S. Patent No. 5,821,186.

[12]. J. L. Collins, R. J. Lauf, and K. K. Anderson, July 29, 2003, "Method of Preparing Hydrous Iro Oxide Gels and Spherules," U.S. Patent No. 6,599,493 B2.

[13]. J. L. Collins and K. K. Anderson, 2001, Development of Spheroidal Inorganic Sorbents for Treatment of Acidic Salt-bearing Liquid Waste, ORNL/TM-2000/367.

[14].J. L. Collins and J. S. Watson, 2000, Economic Evaluation for the Production of Sorbents and Catalysts Derived from Hydrous Titanium Oxide Microspheres Prepared by the HMTA Internal Gelation Process, ORNL/TM1999/212.

[15]. R. J. Lauf, K. K. Anderson, F. C. Montgomery, J. L. Collins, and J. J. Felton, 2004, "Method for Preparing Dielectrics Composite Materials Use Thereof," U.S. Patent No. 2004/6,821,474.

[16]. R. J. Lauf, K. K. Anderson, F. C. Montgomery, J. L. Collins, and J. J. Feldon, 2003, "Method of Preparing Spherical Ferrite Beads and Use Thereof," U.S. Patent No. 2003/0129387 A1.

[17]. R. J. Lauf, K. K. Anderson, F. C. Montgomery, and J. L. Collins, 2002. "Method of Preparing Spherical Ferrite Beads and Use Thereof," U.S. Patent No. 6,492,016 B1.

[18] N. Kumar, R.K. Sharma, V.R. Ganatra, S.K. Mukerjee, V.N. Vaidya, and D.D. Sood, 1991, Studies of the preparation of thoria and thoria-urania microspheres using an internal gelation process: Nuclear Technology; (United States); 96, p. 169-177.

[19] J. L. Collins, and R.D. Hunt, 2003, Uranium Kernel Formation via Internal Gelation, International Conference on Nuclear Technology: Oak Ridge National Laboratory, Achieving Global Economic Growth While Safe guarding the Environment: p. 35. 
[20] S.S. Pathak, I.C. Pius, Bhanushali, R.D., Rao, T.V.V., and S.K. Mukerjee, 2008, Preparation of porous zirconia microspheres by internal gelation method: Materials Research Bulletin, ELSEVIER, p 2937-2945

[21] J. L. Collins and K. K. Anderson, 2001. Development of Spheroidal Inorganic Sorbents for Treatment of Acidic Salt-bearing Liquid Waste, ORNL/TM-2000/367.

[22] F. S. Lameiras, A. Santos, G. Assis, A. M. M. Santos, W. B. Ferraz, 2007. Obtenção de Microesferas de $(U, T h) \mathrm{O}_{2}$ para o combustível do reator nuclear de alta temperatura. Comissão Nacional de Energia Nuclear - CNEN. UFMG $-M G$.

[23] F. Valmor de Almeida, R. D. Hunt, J. L. Collins. 2010, Pneumatic drop-ondemand generation for production of metal oxide microspheres by internal gelation, Journal of Nuclear Materials, Oak Ridge National Laboratory, 404, 4449.

[24] J. L. Collins, R. D. Hunt, G. D. Del Cul, and D. F. Williams, 2004. Production of Depleted $\mathrm{UO}_{2}$ Kernels for the Advenced Gas-Cooled Reactor Program for Use in Triso Coating development, ORNL/TM-2004/123.

[25] J. L. Collins, M. H. Lloyd, S. E. Shell, 2005. Control of Urania Cristallite Size by HMTA-UREA Reactions in the Internal Gelation Process For Preparing $(\mathrm{U}$, $\mathrm{Pu} \mathrm{O}_{2}$ Fuel Kernels, ORNL/TM-2005/10.

[26] J. L. Collins, Pye S. L., 2008. Determination of Ideal Broth Formulations Needed to Prepare Hydrous Aluminium Oxide Microspheres via the Internal Gelation process, ORNL/TM-2006/121.

[27] R. D. Hunt a, J. D. Hunn, J. F. Birdwell, T. B. Lindemer, J. L. Collins., 2010. The addition of silicon carbide to surrogate nuclear fuel kernels made by the internal gelation process, ORNL/TM, 401 p. 55-59.

[28] R.D. Hunt, F.C. Montgomery, J.L. Collins, 2010, Treatment techniques to prevent cracking of amorphous microspheres made by the internal gelation process. Journal of Nuclear Materials, ORNL/TM, 405 p.160-164.

[29] http://compdent.uthscsa.edu/dig/itdesc.html, 14/12/2012 
[30] J. L Collins, J. S. Watson, 2000, Economic Evaluation for Production of Sorbents and Catalysts Derived from Hydrous Titanium Oxide Microespheres Prepared by the HMTA Internal Gelation Process, ORNL/TM 1999/212.

[31] R. P. Gomes, W. R. Santos, Preparação de Microesferas de Òxido de Tório pelo processo de Gelificação Interna. Centro de Engenharia Química.

[32] T.V. Vittal Rao, Y.R. Bamankar, S.K. Mukerjee, S.K. Aggarwal, 2012, Preparation and characterization of $\mathrm{Li}_{2} \mathrm{TiO}_{3}$ pebbles by internal gelation solgel process, Journal of Nuclear Materials Volume 426, Issues 1-3, p 102-108

[33] R.D. Hunt a, G.W.C.M. Silva a, T.B. Lindemer b, K.K. Anderson c, J.L. Collins, 2012, Preparation of uranium fuel kernels with silicon carbide nanoparticles using the internal gelation process, Journal of Nuclear Materials 427 - p 245248

[34] F. W. van der Brugghens, A. J. Noothout, M. E. A. Hermans, J. B. W. Kanij, and O. Votocek, 1970. "A U (VI)- Process for Microsphere Production," in Proc. Symp. Sol-Gel Processes and Reactor Fuel Cycles, Gatlinburg, Tennessee, May 4-7, 1970, CONF-700502, U. S. Atomic Energy Commission.

[35] M. H. Lloyd, K. Bischoff, K. Peng, H. U. Nissen, and R. Wessicken, 1976, "Crystal Habitand Phase Attribution of U(VI) Oxides in a Gelation Process," J. Inorg. Nucl. Chem p 1141-47.

[36] F. J. Homan, T. B. Lindemer, E. L. Long, Jr., T. N. Tiegs, and R. L. Beatty, 1977. "Stoichiometric Effect on Performance of High-Temperature GasCooled Reactor Fuels from the UCO System," Nucl. Technol. 35, 428-4.

[37] P. A. Haas, J. M. Begovich, A. D. Ryon, and J. S. Vavruska, 1980. "Chemical Flow sheet Conditions for Preparing Urania Spheres by Internal Gelation," Ind. Eng. Chem. Prod. Res. Dev. 19(3), 459-67.

[38] D. P. Stinton, 1983 “Mixed Uranium Dicarbide and Uranium Dioxide Microspheres and Process of Making Same," U.S. Patent No. 4, 367, 184.

[39]. R. D. Spence, V. L. Fowler, and A. D. Ryon, 1983. Equipment for Laboratory-Scale Production of (U,Pu)O2 Spheres by the Internal Gelation Process Using Silicone Oil, ORNL/TM-8696, ORNL/TM, Oak Ridge, Tenn. 
[40] J. L. Collins, M. F. Lloyd, and R. L. Fellows, 1984. Effects of Process Variables on Reaction Mechanisms Responsible for ADUN Hydrolysis, Precipitation, and Gelation in the Internal Gelation Gel-Sphere Process, ORNL/TM-8818.

[41] M. H. Lloyd, J. L. Collins, and S. E. Shell, 1985 "Method of Controlling Crystallite Size in Nuclear-Reactor Fuels," U.S. Patent No. 4,502,987.

[42] J. L. Collins, M. F. Lloyd, and R. L. Fellows, 1987 ,"The Basic Chemistry Involved in the Internal-Gelation Method of Precipitating Uranium as Determined by pH Measurements," Radiochim. Acta 42, p 121-34.

[43] P. A. Haas, V. L. Fowler, and M. H. Lloyd, 1987 "Preparation of Nuclear Spheres by Floatation-Internal Gelation," U.S. Patent No. 4, 663, 093. 